\title{
Assessing Environmental Criteria to Support Forest Connectivity
}

Ivan Vanderley-Silva ( $\sim$ ivanvanderley@yahoo.com.br)

UFSCar: Universidade Federal de Sao Carlos https://orcid.org/0000-0002-8756-2422

Roberta Valente

UFSCar: Universidade Federal de Sao Carlos

\section{Research Article}

Keywords: Landscape ecology metrics, land-use/land-cover, and urban sprawl

Posted Date: June 18th, 2021

DOl: https://doi.org/10.21203/rs.3.rs-465496/v1

License: (c) (i) This work is licensed under a Creative Commons Attribution 4.0 International License. Read Full License 


\section{Abstract}

Establishing forest connection in landscapes under urban sprawl is essential for maintaining the ecological processes and ensuring biodiversity conservation. However, the major challenge is incorporated the ecological network in the land-use/land-cover planning. This way, the main objective of the study was the evaluation of environmental criteria for prioritizing areas to obtain forest functional connectivity in a landscape subject to the urban sprawl. The second objective was to understand how the criteria are associated with the structural forest attributes represented by traditional landscape ecology metrics. The criteria were defined through the literature review, representing the landscape characteristics as the topographic, conflicts, and biotics. The metrics used to characterize the forest structure were perimeter, shape index, and distance to the nearest neighbor. They were generated to a selected group of forest remnants, which represent the landscape forest structure. Sampling the criteria and forest fragments maps (i.e., different maps representing the metrics-values) through the hexagon network, we assessed how the criteria are associated with the structural forest attributes. The statistical analysis used to evaluate these sampled values were The Moran Global (Moran I) and Moran Local (LISA). We obtained that the urban expansion process is diffuse, although it does not occur randomly in our landscape. The criteria slope, TWI, distance from drainage network, distance from highways, distance from the lowdensity urban area, and distance from forest patches have characteristics that support this process. Furthermore, our results indicated a spatial autocorrelation among metrics and after, among metrics and these criteria. Also, we obtained that the external influences on the fragments did not occur randomly and that the criteria act on the landscape. This way, through these criteria, we can identify regions where it is possible to have the persistence of forest fragments, even though in places under the impact of urban sprawl.

\section{Highlights}

- The environmental criteria analysis indicates a diffuse urban expansion process that does not occur randomly.

- Landscapes under urban sprawl have criteria, having value ranges related to forest fragments presence.

- The landscape structure can be represented by environmental criteria that reveal the forest fragmentation effects.

- Environmental criteria support the evaluation of function forest connectivity

\section{Introduction}

The urban sprawl has been worldwide discussed in terms of its negative consequence as the loss of natural habitat, forest fragmentation, and increased barriers to gene flow, that has influenced the ecological connectivity of different species (Mimet, Clauzel and Foltête, 2016; Semper-Pascual et al., 
2018; Gavrilidis et al., 2019; koprowska, Laszkiewicz and Kronenberg, 2020), one of the greatest threats to biodiversity conservation. (Scriven et al., 2019; Madadi et al. 2017).

Some studies showed that these consequences have already affected more than $50 \%$ of the worldwide landscapes (Watson, 2016; Tucker et al., 2018; Tabor et al., 2019) and, that less than a third of the Protected Areas are properly connected (Saura et al., 2017).

The concern is ultimately motived by uncertainties about know how human activities can affect the ecosystem services functions (Dupras et al., 2016), as well as the maintenance of ecological processes, species dispersion, and the specimen persistence in an altered environment (Yabsley et al., 2016).

When the dispersion is low, the damages in the ecosystem services include changes in the carbon production and storage rates (Ziter, Bennet and Gonzalez, 2013), less resistance of communities to environmental fluctuations (Isbell, et al., 2015), causing variation on the population and in the aggregated biomass (Balvanera et al., 2014).

Although, an important point related to the connectivity is that the decrease in its performance is not always linear to habitat loss and/or forest fragmentation (Thompson, Rayfield and Gonzalez, 2017; Semper-Pascual et al., 2018). This is due to the presence of central habitats in the landscape dynamics or the existence of new paths to the species movement (Almenar et al. 2019), that can preserve the functioning and stability of the ecosystem (Wang and Loreau, 2016). Still, in function to the pattern and dispersion capacity of individuals (Bergsten and Zetterberg, 2013), who interact, in environments under urban sprawl, with the connectivity to support viable communities, which in turns can suffer from genetic selection and changes in allele frequency (Edelsparre, Shahid and Fitzpatrick, 2018).

According to Perky et al. (2018) the urban sprawl impacts in different ways distinct species, due to their intrinsic resilience ability. This way, the functional connectivity modeling can be skewed if it is only based on one species (Almenar et al., 2019), as well as overestimated if we do not consider the response time to habitat loss and deforestation (Semper-Pascual et al., 2018).

In this context, contemporary models and indices have also been developed not only based on species, but including environmental criteria, indicators, and/or parameters. An example is models based on the graph theory as the least-cost path analysis (Matos et al., 2019; Tarabon et al., 2019; Ribeiro et al. 2020) and circuit theory (Pelletier et al., 2017; Merrick and Koprowski, 2017; Koen, Bowman, and Ellington, 2019), as well as hybrids between least-cost path analysis and circuit theory (Monaco et al., 2020).

Other studies have been supported their decision based mainly on environmental criteria (Valente, Petean, and Vettorazzi, 2017; Torrella et al., 2018; Balzotti et al., 2020), considering their ability to represent the landscape characteristics. Loro et al. (2016) mentioned that methods based on environmental criteria can introduce substantial variability in the evaluation process.

According to Valente, Petean, and Vettorazzi (2017), the criteria represents the critical characteristics related to the study objective. This way, the adequate criteria set selection is essential to obtain robust 
results, independently of the method that will be used in the analysis (Vettorazzi and Valente, 2016).

Zeller, McGarigal, and Whiteley (2012) pointed out that several criteria can support the connectivity analysis as relief shape, proximity among forest native remnants, drainage network, and urban areas.

Loro et al. (2016) highlighted the proximity among remnants because is it related to the species movement in the landscape, considering that variation in the proximities can modify the dispersion resistance of the species. Acevedo, Real, and Gortázar (2011) suggested a criterion, that represents an effective distance from disturbance sources, considering their impact on the functional connectivity. Pays et al. (2012) also indicated the relief shape as an important criterion since some animals show a preference for certain characteristics of the landscape relief.

Ibanez et al. (2014) emphasized the influence of environmental conditions for the connectivity, considering its correlation with landscape structure.

Conversely, we have the traditional landscape metrics, which have been used to evaluated changes in the composition and configuration (i.e. structure) of the landscape (McGarigal, 2013). For decades, the metrics were used to study processes as habitat loss and forest fragmentation (Cheung, Brierley; O'Sullivan, 2016) as well as to evaluated impacts on abiotic and biotic functions (Lausch and Herzog, 2002).

Basing in the landscape metrics, Uezu et al. (2005) studied the importance of fragment size and connectivity (structural and functional) on the occurrence and abundance of bird species. The study exemplified the potential of metrics to characterize the landscape structure, supporting analysis related to processes as well as their ability to provide information, when they are associated with other methods.

Concerning these abilities, Schindler et al. (2013) and Senzaki and Yamaura (2016) cited the metrics as an adequate tool for the identification of forest areas with high conservation value. In the same way, the representativeness of the forest fragments metrics were reported to evaluate the species dispersion and abundance pattern (Economo and Keitt, 2010), a species-area relation (Hammus and Von Nümers, 2008), the herbivores aggregation in the herd (Borthagaray, Arim and Marquet, 2012), and the plant-pollinator interaction (Van Geert, Van Rossum, and Triest, 2009).

The major challenge is the selection of an adequate metric set, which can be done through a literature review (Frank et al., 2013; Lechner et al., 2013). In the case of ecological analysis prevails the metrics of area, edge, and connectivity (Cheung, Brierley and O'Sullivan, 2016; Senzaki and Yamaura, 2016; Schindler et al., 2015), that reflect the forest fragments characteristics in terms of biodiversity (Pereira et al., 2013).

In this context, the main objective of the study was the evaluation of environmental criteria for prioritizing areas to obtain forest functional connectivity, in landscape subject to the urban sprawl. The second objective was to understand how the criteria are associated with the structural forest attributes, represented by traditional landscape ecology metrics. 
Newbold et al. (2015) cited that the maintenance of forest functional connectivity is an important component for biodiversity conservation, in landscapes under urban sprawl, especially when the ecological network is incorporated into the land-use/land-cover planning (Huang et al., 2019; Grădinaru et al., 2017). The importance of theme has been highlighted in the literature, basing on results that showed the connectivity analysis can support the effectiveness of forest conservation schemes (Ayram et al., 2016; Matos et al.2019; Almenar et al., 2019).

\section{Material And Methods}

\subsection{Study Area}

The landscape studied (Fig. 1) is in the Green Belt Biosphere Reserve (GBBR) of São Paulo (SP), which is one of the largest cities in the South America (IBGE, 2021). The city has suffering with the urban sprawl, resulting in pressure in its surrounding area, in terms of conversion to urban use and to agriculture.

The GBBR-SP region is an example of this situation, considering that its agricultural production has as main destination São Paulo city. This way, the urban sprawl occurs in areas originally occupied by Atlantic Forest, affecting ecosystem services (ES) (González-García et al., 2019; Yuan et al., 2019) as the biodiversity (Newbold et al. 2015; Tabaron et al., 2020), water quality (Mello et al., 2020; Klink, Aversa, and Empinotti, 2019) and the forest connectivity (Almenar et al., 2019). Lembi et al. (2020) pointed out also the loss of matrix permeability as another negative effect of the urban sprawl.

Studies have been conducted to minimize these negative effects (Newbold et al. 2015; Ayram et al., 2016; Ribeiro et al. 2020); and we focus on one SE, that is forest connectivity, thinking in the importance of the GBBR areas. According to Unesco (2019), in these areas the human and environmental conflicts should be solved through the efforts of the local and scientific communities, aiming at the sustainable use of natural resources.

The study area is characterized by an urban-rural transition, however, has $34.9 \%$ of its area $(165099.25$ ha) covered by Atlantic Forest remnants belongs to Ombrophilous Dense Forestry (IBGE, 2012). Some remnants belong to Protected Area as the Cabreúva Environmental Protection Area (EPA) in the North, Morro Grande Forest Reserve (FR) in the South, and Itupararanga EPA in the Southwest (Fig. 1). In this scenario, the studied area was considered of extreme importance for the biodiversity conservation and to design ecological corridor (MMA, 2019).

Other remnants are scattered through the matrix composed predominantly by pastures (i.e. anthropic fields) and urban areas, that occupy $36.3 \%$ and $22.4 \%$ of the total study, respectively. Furthermore, in the area there is $3.4 \%$ of planted forests (Eucalliptus $s p$ ), $1.4 \%$ of farmlands, $1.0 \%$ water and $0.6 \%$ of roads (highways and rural roads), as show Fig.1

\subsection{Conceptual Model}


The conceptual framework model (Fig. 2), for our study area in GBBR-SP, includes the environmental criteria and landscape ecology metrics at fragment level, that were spatialized in the Geographic Information System (GIS).

Environmental criteria were group according the landscape characteristic as follow:

- Topographic: slope, aspect, and Topographic Wetness Index (TWI).

- Conflicts: distance from highways, distance from drainage network, and distance from low-density urban area; and

- Biotics: Normalized Difference of Vegetation Index (NDVI) and distance from forest patches.

The database used to produce the criteria as well as the justification of them, in the context of connectivity analysis, will be described in the section below.

The landscape metrics used to characterize the forest structure were perimeter, shape index, and distance to the nearest neighbor. They were generated to a selected group of forest remnants, which represent the landscape forest structure.

Sampling the criteria and forest fragments maps, (i.e. different maps representing the metrics-values) through the hexagon network, we assessed how the criteria are associated with the structural forest attributes. The statistical analysis used to evaluate these sampled values were The Moran Global (Moran I) and Moran Local (LISA) (Fig. 2).

\section{3 criteria selection}

The criteria were defined through the literature review in the period from 2015 to 2019, using platforms as Scielo, Scopus, Web of Science, and Google Scholar. We defined a combination of search terms with sufficient comprehensiveness to maximize the finding of environmental criteria. Since they represented the integration of forest functional connectivity and conservation principles.

The most mentioned criteria, despite differences in nomenclatures, were related to forest cover, topography, water resources, urban area, highways, and soils (Table 1 ).

Table 1 - Environmental criteria for connectivity analysis, that were select from literature I the period from 2015 to 2019 , for the study area in the GBBR-SP, Brazil. 
Reference Study

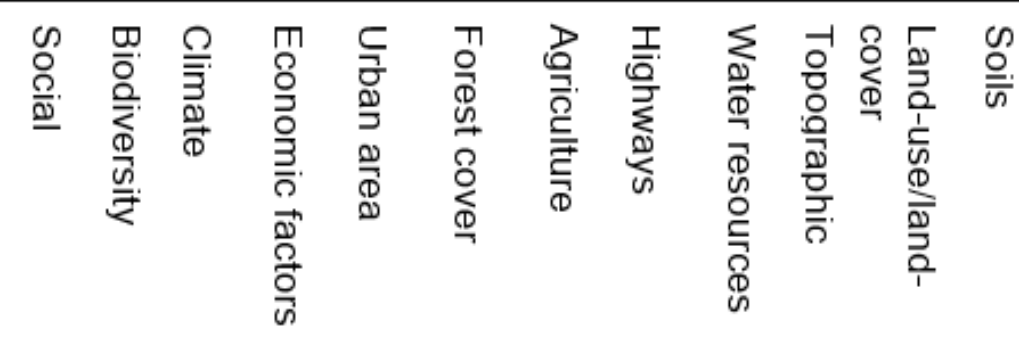

\begin{tabular}{|c|c|c|c|c|c|c|c|c|c|c|c|}
\hline Ayram et al., 2016 & & $x$ & & $x$ & $x$ & $x$ & $x$ & $x$ & $\mathrm{x}$ & $x$ & \\
\hline Curiel-Esparza et al., 2015 & & & $\mathrm{x}$ & $\mathrm{x}$ & $\mathrm{x}$ & & $\mathrm{x}$ & $\mathrm{x}$ & $\mathrm{x}$ & $\mathrm{x}$ & $\mathrm{x}$ \\
\hline Fernádez and Morales, 2016 & & & & & $\mathrm{x}$ & & & & & $\mathrm{x}$ & \\
\hline Lakicev et al., 2014 & $\mathrm{x}$ & $\mathrm{x}$ & $\mathrm{x}$ & & $\mathrm{x}$ & & $x$ & & & & \\
\hline Mello et al., 2018 & & & & $\mathrm{x}$ & $\mathrm{x}$ & $x$ & $\mathrm{x}$ & & $\mathrm{x}$ & & \\
\hline Rincón, et al., 2019 & & $x$ & & & $x$ & & & & & $x$ & \\
\hline Santos et al., 2018 & & & & $\mathrm{x}$ & & & $\mathrm{x}$ & $\mathrm{x}$ & $\mathrm{x}$ & $\mathrm{x}$ & $\mathrm{x}$ \\
\hline Silva et al., 2017 & & & & & & & & $x$ & $\mathrm{x}$ & $\mathrm{x}$ & \\
\hline Unda and Etter, 2019 & & $\mathrm{x}$ & & & $\mathrm{x}$ & & & & & & \\
\hline Vettorazzi and Valente, 2016 & & & & & & & $\mathrm{x}$ & $\mathrm{x}$ & & $\mathrm{x}$ & $\mathrm{x}$ \\
\hline
\end{tabular}

The selection of the environmental criteria, among the most cited, was based on the study area characteristic, considering that is a landscape under urban sprawl; the main justificative of the author to use a criterion; and the criterion representativeness in terms of environmental characteristics.

This way, the selected criteria were slope, aspect, Topographic Wetness Index (TWI), distance from highways, drainage network, distance from low-density urban areas, Normalized Difference of Vegetation Index (NDVI), and distance from forest fragments. As mentioned in the conceptual model section, they were group in topographic, conflicts, and biotics.

The first three criteria and the drainage network were produced from the Digital Elevation Model (DEM) of the study area, which was produced from the Shuttle Radar Topography Mission (SRTM) model (https://earthexplorer.usgs.gov/). The 10-m contour lines were extracted from the SRTM model (30mspatial resolution) and interpolated (nearest neighbor method) with a $20 \mathrm{~m}$-spatial resolution, to the DEM integrate our geographic database. In the GIS environment, watershed and slope/aspect plug-ins were used to generate these criteria.

The other criteria were produced from features (i.e. highways, low density urban areas, and forest patches) extracted from the land-use/land-cover map (Fig.1), which resulted from a supervised classification (Maximum Likelihood algorithm) of CBERS-4 satellite images (20m-spatial resolution). The map presents $90 \%$ accuracy, according to a field verification (in the 2019 year) based on 140 points randomly stratified across the study area.

This way, we obtained the Euclidian distance from highways, low-density urban areas, and forest patches, calculating also the NDVI from the last feature. The low-density urban areas are small urban 
agglomerations or farms characterized by a horizontal, dispersed, and polycentric growth. Conversely, the highly dense urban areas were classified as constraints, considering their low quality for support he functional connectivity, have a compact, vertical and monocentric shape (Ojima, 2007).

The NDVI index considers the relation between the energy reflected in the red and near-infrared wavelengths to represents the vegetation biomass. The index varies from -1 to +1 , with the last value indicating vegetation denser, moist, and well-developed (Melo et al., 2011). In this context, we used NDVI to represent the forest vegetation vigor (Anatoly, Peng, and Huemmrich, 2014).

The principal component analysis (PCA) was used to explain the organization and variability of criteria in the landscape.

PCA is a linear method for the exploratory data analysis of multidimensional statistical series, that aimed the reduction of variables (no significant) without information loss (Borcard, Gillet, and Legendre, 2011).

\subsection{Forest patches metrics}

The metrics used to characterize a selected group of patches, that represented the landscape forest structure, were area, perimeter, shape index, and distance to the nearest neighbor. According to Pereira et al., 2013; Mello, Toppa and Cardoso-Leite, 2016; Palmero-Iniesta et al., 2020 these metrics also support the forest patches description in terms of connectivity and conservation.

Firstly, we divided the forest remnants into size classes, having the prerogative that the forest area represented by these classes should be similar. The analysis guaranteed the representativeness of patches with different sizes, excluding the specifics categories influence as those that occupied a small area or that contained a large area concentrated on restricted patches. This way, the actual condition of the landscape under study was represented, as illustrated in Fig. 1.

After, the patches were identified individuality in a map, that was used to calculate the metrics through the Vector Based Landscape Analysis Tools Extension (V-Late), in the GIS environmental.

The metrics values were associated with their respective patches to compose maps, representing their perimeters, shapes, and distances to their nearest neighbor.

\subsection{Criteria and forest structure Evaluation}

We assessed how the criteria are associated with the forest patches metric (representing the structural forest attributes) based on a hexagon network sampling (Fig. 3).

Through this network, we sampled the maps of criteria and metrics, considering hexagons that covered more than $50 \%$ of the patch size (Fig. 3.) As the size of hexagon-unit was 2 ha, at least two sample points by patch were obtained. 
These sampled values supported the statistical analyses. Using Moran Global (Moran I) (Moran, 1950) and Moran Local (LISA) indexes (Anselin, 1995), we evaluated the spatial autocorrelation of the criteria, metrics, and finally among the criteria and metrics.

The first index varies from 0 to +1 , indicating a direct correlation, and from 0 to -1 , that reflected an inverse correlation. Otherwise, LISA asses the autocorrelation degree, weighted by geographic proximity and it indicates regional grouping.

For the two indexes, the significance level considered was $p<0.05$, that was calibrated for the Euclidean distance from the average point of the sample space.

The canonical correspondence analysis (CCA) tested the hypothesis that the metrics can indicate the criteria importance rank to the forest functional connectivity, revealing these criteria influence under the forest patches.

The vegan package ( $\mathrm{R}$ software) supported the canonical correspondence analysis, after the preverification of multicollinearity for values greater than 5 (James et al., 2014) and the validation of product with $p<0.05$ through permutation and ANOVA tests.

\section{Results}

The environmental criteria, selected from the literature review (from 2015 to 2020), considering terms as forest functional connectivity, connectivity and forest conservation, and landscape subject to urban sprawl, among others are listed in Table 2. 
Table 2

- Criteria importance for forest functional connectivity analysis, in the forest conservation context, according to literature review.

\section{Feature Criteria Importance}

Topographic Aspect Aspect has an effect on the diversity, regeneration, and structure of tropical and temperate forests worldwide (Wagner et al. 2020, Tiwari et al. 2020, Ou et al., 2020, and Hollunder et al. 2021). In the same way, the criterion can reveal sensitive places from a topographic perspective, that are especially the faces with minor moisture retention ability. Faces that should be cover by native vegetation, aiming to avoid problems as soil erosion (among others). This way, we think in the prioritization of these sensitivity regions to obtain forest functional connectivity, as a way to the maintenance of landscape feature.

Slope It is the main criterion related to soil erosion, considering (Valladares et al., 2012).

Since high slopes reduce human access, the criterion is an important physical attribute for forest regeneration. on the other hand, sloping land has less water and soil retention capacity, which can reduce the forest regeneration rate. These reasons could explain why elevation has a positive effect on the change rate of the forest cover, while the interaction between slope and elevation can have a significant negative effect (Li et al., 2013).

Regions associated with high levels of slope have been indicated as susceptible to erosion processes, the criterion is highlighted in the literature related to soil erosion (Haidaraa et al. 2019)

TWI

Wetlands are important ecosystems as they provide habitat for plants and animals and improve water quality (Guo et al., 2017). The topographic wetness index (TWI) is used to identify the saturated areas and to distinguish the reliefs where there are well-drained soils ( $O^{\prime} N$ Neil, Goodall and Watson, 2018).

For this reason, topography shapes and restricts vegetations, causing a number of environmental conditions that are favorable to many communities and to the ecosystem process. This allows for the detection of patterns of species with different resource habitat requirements as correlated with attributes such as river valleys, mountainous regions and other varied topographies (Czarnecka, Rysiak and Chabudzinski, 2017).

Biotic NDVI

NDVI is a robust metric for estimating forest cover and its development status, as it produces a strong estimate of the chlorophyll concentration in the leaf (Nagai et al., 2010).

The richness of species increases with the vegetation structural heterogeneity and biomass. More complex stretches provide more resources and opportunities for microhabitat segregation (Wood et al., 2013). 


\begin{tabular}{|c|c|c|}
\hline Feature & Criteria & Importance \\
\hline & \multirow[t]{3}{*}{$\begin{array}{l}\text { Distance } \\
\text { from } \\
\text { Forest } \\
\text { Patches }\end{array}$} & $\begin{array}{l}\text { The distribution pattern of mature forests, combined with the } \\
\text { disturbance, and replacement of old forests, can influence the } \\
\text { dispersion of species, movement and processes at the population level } \\
\text { and define whether species adapt or perish in altered forest ecosystems } \\
\text { (Ruffell, Clout, and Didhan, 2017). }\end{array}$ \\
\hline & & $\begin{array}{l}\text { Habitat reduction, with subsequent increased edge effects, changes the } \\
\text { behavior of individuals and habitat use patterns, also reducing } \\
\text { movement between fragments (Ramesh, Kalle and Downs, 2015). }\end{array}$ \\
\hline & & $\begin{array}{l}\text { Proximity to nature reserve areas also affects how people perceive the } \\
\text { importance of forest conservation. As they move away from core areas, } \\
\text { the opportunities and level of anthropic disturbance increase (Deng et } \\
\text { al., 2015). }\end{array}$ \\
\hline \multirow[t]{7}{*}{ Conflicts } & \multirow{3}{*}{$\begin{array}{l}\text { Distance } \\
\text { from the } \\
\text { low- } \\
\text { density } \\
\text { urban } \\
\text { area }\end{array}$} & $\begin{array}{l}\text { In the urban expansion area, there is an increase for work and housing, a } \\
\text { rapid regional economic development (Shiferaw et al., 2019), and a } \\
\text { greater pressure on habitats and systemic services provided (Yuan et al., } \\
\text { 2019). }\end{array}$ \\
\hline & & $\begin{array}{l}\text { In particular, forest fragmentation caused by waterproofing surfaces } \\
\text { threatens species and habitat (McDonald; Marcotulio and Guneralp, } \\
2013) \text {. These threatens effect on the mobility of organisms, being a } \\
\text { central factor in the ecosystem services provision (Mitchell, Bennett, and } \\
\text { Gonzalez, 2013). }\end{array}$ \\
\hline & & $\begin{array}{l}\text { The reduction in connectivity affects the regulation of ecological flows, } \\
\text { which determines the effectiveness of preserved natural areas, observed } \\
\text { through changes in focal species behavior and in the habitats } \\
\text { preference (Ayram et al. 2019). }\end{array}$ \\
\hline & \multirow{3}{*}{$\begin{array}{l}\text { Distance } \\
\text { from } \\
\text { Drainage } \\
\text { Network }\end{array}$} & $\begin{array}{l}\text { In Brazil, environmental legislation determines a minimum reserve of } \\
\text { riparian zone along perennial watercourses within private properties or } \\
\text { public areas (Brasil, 2012). }\end{array}$ \\
\hline & & $\begin{array}{l}\text { This riparian vegetation continues offers an opportunity to establish an } \\
\text { integrated network of forest remnants, which can serve as habitat and } \\
\text { connectors at the regional or local scale, especially when reduced as } \\
\text { sources that cause environmental degradation (Zimbres et al., 2018). }\end{array}$ \\
\hline & & $\begin{array}{l}\text { The riverside areas are dynamic, biologically rich ecosystems, with a } \\
\text { high content of nutrients, humidity and the presence of unique } \\
\text { microclimates for species of invertebrates (Ramey and Richardson, } \\
\text { 2017) terrestrial mammals (Zimbres et al., 2018) and birds (Mitchell et } \\
\text { al., 2018). }\end{array}$ \\
\hline & $\begin{array}{l}\text { Distance } \\
\text { from } \\
\text { Highways }\end{array}$ & $\begin{array}{l}\text { Disturbances caused by highways increase the forest patches edge } \\
\text { effects, decreasing the fauna species presence (Avalos and Bermúdez, } \\
2016) \text {. In addition, highways contribute to increased landscape } \\
\text { fragmentation, as they cut through continuous areas with high } \\
\text { connectivity and create barriers to movement between habitats } \\
\text { (Carvalho et al., 2015). }\end{array}$ \\
\hline
\end{tabular}


The group represents landscape features relating to their topography and biotic components that can support the prioritization of areas to obtain forest function connectivity in the forest conservation context. They also have characteristics representing conflicts for this objective, which can threaten the process (Fig. 4).

This way, the main reason or importance that drove the authors (from the literature review) to include the criteria in their studies are presented in Table 2.

According to the slope criterion (Fig. 4A), approximately $91 \%$ of the study area showed declivity at most $20 \%$. Nearly $47 \%$ of this total presented at most $8 \%$ of declivity and they are concentrated in the South region of the study area (Fig. 4A).

This concentration was also appointed by the LISA index, that classified the region by low-low, indicating the spatial proximity between lowest slope values (Fig. 5A).

In this context, the slope was the criterion associated with the higher value of Moran Index $(I=0.457)$ among the topographic criteria $(\mathrm{TWI}=0.190$ and Aspect $=0.292)$, indicating that its features have a spatial distribution significant positive ( $>0)$ (Fig. 5 ABC).

According to the LISA index results for the criterion, the study area was classified in $20 \%$ as high-high and $21 \%$ as low-low, having significant spatial autocorrelation.

The TWI criterion (Fig. 4B) indicated the South region also associated with the high moisture-retention ability, having values varying from 12 to 27 , that occupy $16 \%$ of the study area.

However, $62,1 \%$ of TWI values varied from $5-12$ and they are spread across the study area, in which values between $5-7,7-9$, and $9-12$ represent $42.8 \%, 14.3 \%$, and $5.1 \%$, respectively. The TWI values greater than 27 totaling less than $1 \%$ of the total, occurring only in the North (Fig. 4B).

Reflecting this spatial pattern of the most features distributed randomly across the landscape, the Moran Index for TWI was 0.190, which was the lowest value obtained among the criteria (Fig. 5B).

In the same way, the LISA index did not identify a significative regional grouping (Fig. 5B), showing only a tendency in the Central-North region of lowest TWI values, which were classified as low-low (with $15.4 \%$ of spatial autocorrelation) (Fig. 5B). However, this tendency is not statistically significant, taking into account the great variability of the criterion features.

The Central-North region was associated with relief Heavily-Undulating (20-45\%) and Hilly (>45\%) (Fig. $4 \mathrm{AB}$ ), having a spatial distribution significantly positive (Fig. $5 \mathrm{C}$ ). As mentioned, the LISA index indicated groupings in those regions, that were classified as high-high because of the high spatial correlations between near features (Fig. 5C).

The LISA index also showed groupings for the aspect criterion in the Central-North region classified as high-high (16.2\%) and low-low (16.3\%) (Fig. 5C), considering the predominance of faces oriented for east- 
west direction (Fig. 4C).

However, Fig. 4C illustrated these faces spread across the landscape and interacting with others, resulting in a low value of Moran Index $(I=0.292)$, as we observed for TWI. The east-west faces occupied $65.3 \%$ of the landscape and north-south faces $34.7 \%$ (Fig. 4C).

Similarly, the distance from the drainage network showed its watercourses spread by the landscape (Fig. 4D), obtaining the Moran index of 0.477. The value was superior to the TWI and aspect, indicating a positive autocorrelation in the spatial distribution of the watercourses, although with a low level, having only $18 \%$ classified as high-high and $23 \%$ as low-low (Fig. 5D).

The maximum distance from the drainage network was $800 \mathrm{~m}$, although values at most $200 \mathrm{~m}$ from watercourses represented $56 \%$ of total area and between $200-400 \mathrm{~m}$ approximately $36 \%$ (Fig. 5D).

Basing on the low-density urban areas and highways, the maximum distances obtained were, respectively, $8200 \mathrm{~m}$ and $16482 \mathrm{~m}$, mainly in the function of the values present in the extremes of North and Southeast (Fig. 4E and Fig. 4F).

This way, those features presented more influence in the Central-to-South-west portion of the landscape, where we can also observe the great urban areas, which were classified as a restriction to functional connectivity because of their low quality. Due the presence of these conflicts features the region was classified as low-low (LISA index), showing significant spatial autocorrelation of $41.5 \%$ for low-density urban area and $41.4 \%$ for distance from highway.

Consequently, this region has significant positive spatial autocorrelation with regions classified as highhigh represented 14.0\% (low-density urban area) and 16.8\% (distance from highways) (Fig. 5E and Fig. $5 F)$. However, the spatial autocorrelation of distance from highway is slightly higher than the distance from low-density urban areas, considering their Moran index values of 0.992 and 0.976 .

The urban areas and highways influenced on the forest patches spatialization through the landscape, that presented $11268 \mathrm{~m}$ as the maximum distance among them (Fig. 4h).

The criterion showed Moran index value of the 0.992 , that reflects the high and positive correlation among the distances from forest patches. Thus, the LISA index showed region grouping (with high autocorrelation degree) classified as high-high (29.2\% spatial autocorrelation) (Fig. 5h) and located in the central region of the landscape.

The high-high class indicates place associated with a high probability to occur the great distance values, near other places in the same condition. For the study, in the same region that the LISA index indicated the low-low (38.6\% of spatial autocorrelation) groupings for the distances from low-density urban areas and highways (i.e. concentration of places near to the conflicts features). 
This way, the spatial autocorrelation analysis indicated that the great distance from the forest patches occurred in places occupied by urban areas and highways.

Finally, Fig. 4g showed the NDVI index, having its highest values associated with the largest forest patches.

Although, its Moran Index was 0.50 , indicating that the criterion has a minor autocorrelation degree than the criterion distance from the forest patch.

Figure $5 \mathrm{~g}$ illustrated the groupings detected through the LISA analysis, that were classified as high-high (23.7\% of spatial autocorrelation) and were in similar regions of the distance from forest patches criterion. However, the spatial autocorrelation of this criterion is smaller than the last.

Relating to the criteria variability, PCA analysis explained $42.58 \%$ of the data (Fig. 6) According to the first axis the slope decreases as the distance from the drainage network and aspect values also decrease. Conversely, TWI values increase (Fig. 6).

Figure 6 showed in the second axis that, as the forest patches are coming toward the low-density urban areas and highways, there is a decrease in the distance value among forest patches and the NDVI index.

\subsection{Forest structure evaluation}

The study area has 57665.75 ha covered by 10428 Atlantic Forest remnants with sizes varying from 0.04 ha to 11248.31 ha.

According to Table $3,92.5 \%$ of these remnants have less than 5 ha, however, they represented only $5.9 \%$ of the total native forest area. 
Table 3

Distribution of patches by size classes and the forest metrics values (mean and standard deviation) applied to forest structure evaluation of the study area in the GBBR-SP (Brazil).

\begin{tabular}{|c|c|c|c|c|c|c|}
\hline Class & NP & Area & Forest patches $\mathrm{m}$ & & & \\
\hline (ha) & $(\%)$ & $(\%)$ & AREA (ha) & PERIM (m) & $\operatorname{NEAR}(\mathrm{m})$ & SHAPE \\
\hline$<5$ & 92.5 & 5.9 & $0.36 *( \pm 0.79 \star \star)$ & $277.90( \pm 299.03)$ & $17.80( \pm 42.46)$ & $\begin{array}{l}1.15( \pm \\
0.24)\end{array}$ \\
\hline $5-30$ & 5.2 & 11.5 & $12.32( \pm 6.37)$ & $\begin{array}{l}2857.48( \pm \\
1301.65)\end{array}$ & $\begin{array}{l}107.67( \pm \\
162.66)\end{array}$ & $\begin{array}{l}2.05( \pm \\
0.60)\end{array}$ \\
\hline $30-75$ & 1.3 & 11.0 & $47.00( \pm 13.57)$ & $\begin{array}{l}7814.90( \pm \\
2366.13)\end{array}$ & $57.57( \pm 98.93)$ & $\begin{array}{l}2.85( \pm \\
0.65)\end{array}$ \\
\hline $75-170$ & 0.6 & 11.2 & $105.98( \pm 24.89$ & $\begin{array}{l}13933.64( \pm \\
4035.25)\end{array}$ & $38.88( \pm 77.14)$ & $\begin{array}{l}3.38( \pm \\
0.82)\end{array}$ \\
\hline $\begin{array}{l}170- \\
300\end{array}$ & 0.3 & 10.4 & $244.71( \pm 28.74)$ & $\begin{array}{l}26434.43( \pm \\
6538.71)\end{array}$ & $21.56( \pm 35.60)$ & $\begin{array}{l}4.40( \pm \\
0.95)\end{array}$ \\
\hline$>300$ & 0.2 & 50.0 & $\begin{array}{l}1436.24( \pm \\
2689.73)\end{array}$ & $\begin{array}{l}92797.11( \pm \\
107803.9)\end{array}$ & $0.00( \pm 0.00)$ & $\begin{array}{l}6.50( \pm \\
2.23)\end{array}$ \\
\hline
\end{tabular}

Otherwise, we observed that $0.2 \%$ of the total patches (i.e. 21 patches) occupying $50 \%$ of the total forest area. Most of these restricted group belongs to three Protect Areas, located inside the study area i.e. Cabreúva EPA and Morro Grande FR (Fig. 1).

This way, the pattern of forest patches that are distributed through the landscape studied have sizes varying from 5 ha to 300 ha. As predefined for this study, their size classes are occupying similar percentage of the native cover (Table 3).

The remnants belonging to the $5-30$ ha class represented $5.2 \%$ of the total forest patches, while the class with $30-75$ ha represented $1.3 \%$, the class with $75-170$ ha represented $0.6 \%$, and the patches with $170-$ 300 ha accounted $0.3 \%$. Their mean patch sizes were, respectively, $12.32(\mathrm{SD}= \pm 6.37), 47.00(\mathrm{SD}= \pm$ 13.57), $105.98(\mathrm{SD}= \pm 24.89)$, and $244.71(\mathrm{SD}= \pm 28.74)$, with the standard deviation values together increases the mean size (Table 3).

Similarly, the PERIM and SHAPE metric values (mean and SD) increased as the patch sizes were increased (Table 3). The mean metrics values were, respectively, $2857.48 \mathrm{~m}$ and 2.05 (5-30 ha), $7814.90 \mathrm{~m}$ and 2.85 (30-75 ha), $13933.64 \mathrm{~m}$ and 3.38 (75-170 ha), and $26434.43 \mathrm{~m}$ and 4.40 (170-300 ha). 
Conversely, the NEAR metrics value (mean and SD) decreased as the mean patch size increased. According to Table 3 the distance among forest patches were $107.67 \mathrm{~m}$ (5-30 ha), 57.57m (30-75 ha), $38.88 \mathrm{~m}$ (75-170 ha), and 21.56m (170-300 ha).

According to the Moral Index (Fig. 7), the metrics presented significant and positive spatial autocorrelation. Although, the spatial autocorrelation of NEAR (1.000) was slightly higher than the AREA (0.971), PERIM (0.968), and SHAPE (0.963).

Consequently, the LISA index indicated groupings in regions with spatial proximity between similar characteristics (Fig. 7).

In the case of the NEAR metric (Fig. 7), we can highlight groupings classified as low-low in the central portion of the study area. They represented the concentration of areas with high distance values from forest patches.

For the other metrics, we can highlight the small low-low groupings, representing the concentration of the largest patches, characterized by the greatest perimeters and irregular shapes (Fig. 7b-d).

\subsection{Criteria and Forest Structure Analysis}

The patches, representing the forest structure of the study area, were associated with criteria characteristics, as described in Table 4.

Relating to the slope criterion, they were predominately associated with regions varying from $6.66-17 \%$ declivity (Slope mean $=11.83 \%$ ), that compound the $91 \%$ of the study area with declivity at most $20 \%$ (Fig. 4A). However, there is forest patches associated reliefs flats (Slope $\min =0.002 \%$ ) as well as HeavilyUndulating (Slope $\left.\max _{\max }=36.36 \%\right)($ Table 4).

Table 4

Variability of criteria characteristics for the forest patches of the study area in the GBBR-SP, Brazil.

\begin{tabular}{|c|c|c|c|c|c|c|c|c|}
\hline Param. & $\begin{array}{l}\text { Slope } \\
\text { (\%) }\end{array}$ & TWI & Asp & $\begin{array}{l}\text { Drainage } \\
\text { (m) }\end{array}$ & $\begin{array}{l}\text { Urban Area } \\
\text { (m) }\end{array}$ & $\begin{array}{l}\text { Highway } \\
\text { (m) }\end{array}$ & $\begin{array}{l}\text { Patches } \\
\text { (m) }\end{array}$ & NDVI \\
\hline Min. & 0.002 & 3.89 & 4.80 & 9.33 & 39.20 & 30.01 & 59.12 & 0.32 \\
\hline Max. & 36.36 & 24.89 & 344.90 & 734.32 & 5843.357 & 13252.03 & 8542.66 & 0.69 \\
\hline Mean & 11.83 & 7.08 & 177.03 & 199.27 & 829.44 & 1680.86 & 2440.01 & 0.58 \\
\hline $\mathrm{SD} \pm$ & 5.17 & 2.27 & 70.67 & 126.48 & 878.10 & 1844.85 & 1671.40 & 0.03 \\
\hline \multicolumn{9}{|c|}{$\begin{array}{l}\text { Where: Slope = Slope; TWI = Topographyc Wetness Index; Asp = Aspect; Drainage = Distance from } \\
\text { Drainage Network; Urban Area = Low-Density Urban Area; Highway = Distance from Highways; } \\
\text { Patches = Distance from Forest Patches; NDVI = Normalized Difference Vegetation Index. Param. = } \\
\text { Parameter. }\end{array}$} \\
\hline
\end{tabular}


We defined the predominant pattern for the criterion based on its low standard deviation value. Table 4 also indicated TWI and NDVI in the same situation.

This way, regions associated with the forest patches showed TWI varying from 4.81 to $9.35\left(\mathrm{TWI}_{\text {mean }}=\right.$ 7.08). Values that integrated this more range frequently of moisture-retention ability were observed in the landscape (Fig. 4B)

Relating the aspect criterion, the mean value indicates a tendency of the patches to be placed on the EastWest face $\left(\right.$ Aspect $\left._{\text {mean }}=177.03\right)$. Although, the high variation value of SD $\left(\right.$ Aspect $\left._{\text {sd }}=70.67\right)$ cannot support the pattern definition for those regions. Especially, when we consider its spatial pattern of the majority features distributed randomly across the landscape, which was indicated by the Moran Index ( $I=$ 0.292) and the LISA index (Fig. 4e 5C).

Otherwise, we can affirmative that the great part of forest remnants is at mostly $325.75 \mathrm{~m}$ from the watercourses (drainage mean $=7.08$ ) (Table 4), that in $92 \%$ of the landscape are at closest $400 \mathrm{~m}$ from the rivers (Fig. 4D).

The forest patches also presented mean distance from the low-density urban area and highways of $829.44 \mathrm{~m}$ (SD: $\pm 878.10 \mathrm{~m}$ ) and $1680.86 \mathrm{~m}$ (SD: $\pm 1844.85 \mathrm{~m}$ ) (Table 4), respectively. The conflict criteria maps (Fig. 4EF) indicated those features spread by the landscape with $71 \%$ of urban areas and $14 \%$ of road at most $2000 \mathrm{~m}$ from the forest remnants.

However, these criteria maps presented the highest spatial autocorrelation (Moran $\mathrm{I}_{\text {urban }}$ :0.976 and Moran $_{\text {highway }}$ l:0.992) values among the criteria with groupings (LISA index) in the landscape Central region, representing the concentration of this features. The LISA index also indicated groups far from the central regions, that were associated with high distances from the features, explaining these Standard Deviation values (Table 4).

According to Table 4, the forest patches showed mean distance among then of $2440.01 \mathrm{~m}$ (SD: \pm 1671.40 $\mathrm{m})$. As the last two criteria, the mean values and standard deviation values reflects the presence of the patches through the landscape (Fig. 4g). The same way, the criterion presented the highest spatial autocorrelation values (Moran I: 0.992) among the criteria, supporting the concentration of remnants in same regions of the landscape. Where the NEAR metric (Table 3) indicated values varying from $21.56 \mathrm{~m}$ to $107.67 \mathrm{~m}$ for patches grouped in similar size classes. Still, the minimum distance indicated in Table 4 was $59.12 \mathrm{~m}$.

This way, the criterion reflected the forest patches scattered across the landscape, having a mean distance among them of $2440.01 \mathrm{~m}$, but with some remnants near to each other (Dist_patch ${ }_{\mathrm{min}}=$ $59.12 m)$.

The mean NDVI index of these patches varies from 0.55 to $0.61\left(\mathrm{NDVI}_{\text {mean }}=0.58\right)$, which was the minor range of SD, among the criteria (Table 4). We obtained these values based on a hexagon network 
sampling, obtaining the NDVI values inside of the patches.

The criterion map presented Moran index of 0.500, indicating these small groupings. However, for the landscape prevailed its mainly characteristics, that is the low spatial autocorrelation (Fig. 4h)

Concerning the Canonical correspondence analysis (CCA), Fig. 8 illustrates that the forest patches metrics explain in $84.10 \%$ the criteria ordering.

The data variability was explained in $66 \%$ by the axis 1 and 18.10 by the axis 2 . Through the first, we observed the greatest influence of the metrics NEAR and PERIMETER. While in the second, the main ordering variables were SHAPE and NEAR. However, the area variability was not significant (Fig. 8).

The CCA analysis (Fig. 8) also indicated that the forest patches perimeters values increase as the distance value from the highways increases too. Conversely, decreasing the distance from the low-density urban areas decrease, the distance among forest patches (NEAR) also decreases. Such happens because low-density urban areas are composed of small urban agglomerations, which are scattered among the forest fragments.

In the same way, the aspect, TWI, NDVI, slope, and distance from the drainage network showed variation in their values associated with the metrics SHAPE and PERIMETER. The criteria values decrease when the first metric decrease and the second increase.

Finally, we observed a no-significant relation between the metric AREA and the criterion distance from the forest patches.

\section{Discussion}

The environmental criteria, that were selected through the literature review (Tables 1 and 2), represent important characteristics of landscapes under urban sprawl, in the context of the prioritizing areas to obtain forest functional connectivity (Curiel-Esparza et al., 2015; Lakicev et. al., 2016; Vettorazzi and Valente, 2016; Santos, et al., 2018, and Mello et al., 2018).

The topographic criteria have effects on drainage capacity (Loritz et al., 2019; Hojati and Mokarram, 2016), forest composition and structure (Jucker et al., 2018), habitat reduction and isolation (Zhang, et al, 2018) and, consequently, on species patterns and richness (Li et al., 2019, Russo et al. 2016, and Keeley, Beier, and Gagnon, 2016), which are essential conditions for measuring forest connectivity.

The distance from drainage network criterion indirectly brings the concept and the importance that riparian forests have in maintaining forest connectivity (La Fuente, et al., 2018). Still, the question of the flow among forest patches, that is compromised by the expansion of urban infrastructure, which produces barriers in the landscape (McRae et al., 2012), habitat loss (Alamgir et al., 2019), and changes in animal movement (Dickie et al., 2019). 
As we mention in Table 2, the criteria have different importance for the functional connectivity and forest conservation, representing a part of the process to obtain the main objective. Importance that has been highlighted in the literature review. (Ayram et al., 2016, Fernádez and Morales, 2016, Unda and Etter, 2019 and Rincón et la., 2019).

This way, the criteria selection based on literature review brings robustness to the study, considering that the set was previous evaluated in other researches. Also eliminates the subjectivity that we bring to the project when experts opinion is required, considering the restricted number of people who contributes to the process (Silveira et al., 2014, Valente et. al., 2017 and Mello et al., 2018).

In the case of criteria selected for the study area in the GBBR-SP, Brazil, they are not spatially correlated and no have information overlap (Figs. 4 and 5). Thus, they can be used to prioritize areas to functional connectivity.

Relating the main characteristics bring for the criteria, we obtain through the slope that $91 \%$ of the study area showed declivity at most $20 \%$ (mean value of $11.83 \% ; \pm 5.17$ ) (Table 4 and Fig. $4 \mathrm{~A}$ ). This predominance of declivity value associated with the low variation of its standard deviation supports the definition of a spatial pattern for the criterion, which was identified by LISA index $(I=0.457)$ (Fig. 5A). Kane and John (2018) cited that topographical factors determine land-use decisions by local communities, considering if the relief allows greater accessibility, there is an increase in deforestation (Bax, Franscesconi and Quintero, 2016) and a critical potential for natural regeneration (Molin et al., 2018).

Authors as Adams, Barnard and Loomis (2014) complement that tree growth and forest productivity can be affected by slope, as well as for the TWI and aspect due to influences on runoff and wind exposure. Thus, these factors allow the elaboration of forest connectivity models based on relief, as the species have different habitat requirements (Czarnecka, Rysiak, and Chabudzinski, 2017).

Relating to TWI criterion, we obtained approximately $62.1 \%$ of the total area varying from $5-12$, including soils classified as well-drained (TWI of 4-5), moderately drained (TWI of 5-7), and poorly drained soils (TWI of 7-12) (Li et al., 2006). Approximately $43 \%$ of this total is associated with the moderately drained soils, contributing to classification of this areas as low-low by LISA Index (Fig. 5B), since they are showed a scattered distribution through the landscape.

According to our results, regions associated with the 5-12 TWI range are occupied by forest fragments, showing an average of 7.08 and a low standard deviation $( \pm 2.27)$ (Table 4).

This way, TWI was characterized as a heterogeneous criterion, having Moran Index (I) of 0.190) as also mentioned by Da Silva, Santos and Oka-Fiori (2019).

Similarly, the aspect also was defined as heterogeneous, having an I value of 0.292 , however with a standard deviation of \pm 70.67 , (Table 4). This criterion behavior occurs in our study area, even it characterized by has a topographic divider of water flow and, having $65.3 \%$ of its area associated with 
East-West slopes facing (Fig. 4C). These facings are associated with forest patches groups (LISA index, Fig. 5C), which are the most regular patches of the landscape placed in faces with the lowest aspect values (CCA analysis, Fig. 8). This can be explained by the predominance of anthropic land-use on the east landscape face (Victor et al., 2004).

Aspect reveals a tendency to coming toward the slope values because they came from DEM. However, we cannot establish a statistical and significant pattern between them. Adding the fact, that the criterion does not present high spatial correlation, it cannot be considered adequate for a model of prioritization areas, aiming the functional connectivity. This justified by the uncertainties in connectivity analysis, that the aspect can bring to the model.

According to our results, the aspect is the only environmental criterion not adequate for prioritizing areas to obtain forest functional connectivity, in landscape subject to the urban sprawl.

In the same way that the slope and TWI, the distances from forest patches and drainage network criteria are essential to model of the prioritization of areas subject to urban sprawl (Fig. 4D).

According to these maps the average distance of forest patches from the water courses was $199.27 \mathrm{~m}$, with $56 \%$ of them at most $200 \mathrm{~m}$. Considering that $36 \%$ of the total forest patches is between $200 \mathrm{~m}$ and $400 \mathrm{~m}$ from the river and $\pm 126.48 \mathrm{~m}$ as maximum value of deviation standard (Table 4 ), we obtained that the majority patches (including the $56 \%$ ) is from $325.75 \mathrm{~m}$ from a watercourse.

The distances from the drainage network criterion supported these results. Firstly, because the watercourses are adequately distributed throughout the study area $(I=0.477)$ (Figs. 4 and 5D), that resulted in a high spatial autocorrelation with a value superior to the topographic criteria. Second, because the autocorrelation supported the clusters structuration in regions, where there were the minor distances of the patches from watercourses (LL in LISA), as well as there were the highest (HH) distances (Fig. 5D).

Observing the criterion results, we noticed that they were predominately supported by the relation with the proximity to watercourses, which is the most important region for the main objective. This way, the most adequate name for the criterion is proximity to the drainage network instead of the distances from the drainage network. The name reflects the most important region for the criterion and becomes in accordance with the literature, wherein have been considering riparian forest corridors as the most suitable environment for forest connectivity (La Fuente et al., 2018, Zimbres et al., 2018).

While the watercourses are scattered through the landscape, the main features of the distance from the low-density urban area and highways criteria showed concentrated, mainly, in its Central-to-South-west portion (Fig. 4E and Fig. 4F). Due the presence of the great urban areas and roads, the forest patches cluster of this regions presented spatial autocorrelation classified as LL (Fig. 5E; I = 0.976 and Fig. 5F; I = 0.992). It is noted in the Fig. $4 \mathrm{E}$ that a restricted area was created over consolidated urban agglomerations, to analyze only the effects of urban sprawl on forest remnants. 
However, the features of criteria (roads and urban) and consequently theirs respectively distance maps showed an effect in the forest fragments spatialization. Around $71 \%$ of the forest patches are $2000 \mathrm{~m}$ from an urban area and $86 \%$ of them are $2000 \mathrm{~m}$ from a road.

Anthropogenic disturbance in the landscape favors generalist species that are able to explore environments, such as disturbed habitats (Magioli et al., 2019). Consequently, there is an increase in conflict factors, such running over wildlife (Abra et al., 2021), predation of farm animals (McPherson, Brown, and Downs, 2016), and animals lethal control (Blackwell, et al., 2016), being essential to define the most beneficial actions of conservation planning and implementation (Abra et al., 2021).

Conflict features that showed high spatial correlation (PCA analysis, Fig. 6), indicating that they can compose a unique criterion in future studies. Criterion that brings information related with the connectivity, since that urbans areas and road have crossed landscapes subject to urban sprawl, which have become one of the greatest threats to biodiversity conservation (Scriven et al., 2019; Madadi et al. 2017).

Kuang et al. (2014) cited that the urban expansion process and the relationship with forest fragmentation is an effect of worldwide verification, carried out on the scale of megacities, and due to the increase in the population living in urban areas (Angel et al., 2016). Thus, given that land use can occur in many different patterns, metrics that consider the spatial arrangement of urban infrastructure can better explain landscape fragmentation (Bar-Massada, Radeloff, and Stewart, 2014; Lin and Fuller, 2013).

Relating the importance to maintain the criteria distance from forest patches, our results indicate that we have forest patches supporting the native fauna and flora, especially the group formed by patches with sizes greater than 300 ha (Table 4 and Fig. 4H). As we mentioned, this group is formed by 21 patches, belong to three Protect Areas, located inside the study area, and occupy 50\% of the total forest area. Even more, these forest patches are integrated with others, considering that the minor than they are scattered across the landscape (Table 3 ).

According to Magioli et al. (2019), the large and continuous habitats support populations with more complex trophic structures, acting as a source for biodiversity maintenance in modified habitats. Gibson et al., (2011) complemented that these habitats are essential refuges for wildlife, assuming that their similarity to natural areas (i.e, without anthropic actions).

The Brazilian environmental legislation has been encouraged the conservation of areas as patches greater than 300 ha, however, it is not enough to minimize the urban pressure effect (Romero et al., 2020). In our study areas is not only this group that has potential for connectivity in the studied landscape. We can include the group having medium size too, highlighting the importance of the criterion distances from forest patches. Considering these proximity relations among the forest patches, we can suggest for next studies the name proximity to forest cover as proposed by author as Mello et al., 2018. 
Showing different behavior of other criteria, we have the NDVI. The traditional index represents the forest patches in terms of their status and/or quality (Fig. 4H) i.e., the conditions inside the remnants. Consequently, it is not a criterion that represents the conditions of the natural vegetation on the landscape, as our objective requires.

However, patches-level data are important to support the decision-makers discussion, which guided us to includes our second objective.

For the study area, the patches-level metrics showed coherent resultants, considering the classes areas, that we proposed. The largest forest remnants showed great values of perimeter and shape than the smallest, but minor values of distance among their components (Table 3).

Furthermore, the class areas supporting the evaluation of the spatial autocorrelation among metrics and after, among metrics and criteria.

The results were a high Moran index value for metrics (Fig. 7), which supported in their correspondence with the criteria since these results reflected that the external influences on the fragments did not occur randomly and that the criteria act on the landscape (with $84.1 \%$ of explanation in CCA, Fig. 8).

Different studies have been shown the potential of the ecological metrics in the definition of areas for conservation, on analysis of sprawl urban and evaluation of the landscape structure (Schindler et al., 2013, De Jesus, et al., 2015, Otero et al., 2015, Romero et al., 2018, and Lelli et al., 2019), corroborating with our results.

The CCA analysis (Fig. 8) also indicated that the reduction in the distance from low-density urban areas was associated with a reduction in the distance among forest fragments (NEAR). While the distance from the highways was associated with an increase in the perimeter of the forest patches, and consequently their respective areas. According to Pirnat and Hladink (2018), new diffuse urban areas are not subject to significant changes in terms of habitat size and this seems to happen regardless of population changes (Organization of United Nations Habitat, 2016).

Otherwise, the drier regions of the landscape, on the flatter terrains, near to the rivers, and facing to the east face were associated with our smallest and most irregular patches, that were isolated and presented the lowest NDVI values. Thus, in these landscape regions, the condition related to the urban infrastructure and topography were favorable to human occupation, as also observed by Torres, Jaeger, and Alonso, 2016.

\section{Conclusions}

This study evaluated environmental criteria for prioritizing areas to obtain forest functional connectivity in a landscape subject to the urban sprawl. 
Our study area, the GBBR-SP region, brings the theme importance since its urbanization occurs in areas originally occupied by Atlantic Forest. However, that has its agricultural production destinated to São Paulo city, one of the largest cities in the world. This way, our major challenge is to incorporate a forest network in the land-use/land-cover planning.

Our results indicated that we obtained robust criteria through the literature review, decreasing the intrinsic subjectivity commonly associated with their definition in the participatory technique context. Criteria set composed by slope, TWI, distance from drainage network, distance from highways, distance from a lowdensity urban area, and distance from forest patches. Also, they are not spatially correlated or have information overlap.

In this context, these criteria support identifying regions where it is possible to have the persistence of forest fragments, even though in places under the impact of urban sprawl. Highlighting that we obtained a diffuse urban expansion process in the GBBR-SP region that does not occur randomly.

However, thinking that the criteria names reflect their respective features and importance to the study, the adequate name could be proximity to drainage network and proximity to forest patches instead of distance.

Otherwise, we concluded that aspect and NDVI (originally selected) are not adequate criteria, thinking in prioritize forest areas to functional connectivity, considering that the first showed a heterogeneous behavior through the landscape, revealing a tendency to coming toward the slope values because they came from Digital Elevator Model. The second reflects the patches' quality instead of their potential for forest connectivity.

In this context, we can affirm that the selected criteria reflect the forest structure. Furthermore, they support identifying areas near to watercourses, associated with the deep slope, the greatest moisture retention potential. Areas covered by the great forest patches are the most irregular and connected of the study area.

In this sense, the most distant locations from the highways reflect areas with more preserved forest structure characteristics. However, in areas under diffuse urban expansion, large and connected forest fragments are close to low-density urban environments. Highlighting that these regions are also important for functional connectivity.

This way, our findings indicated a spatial autocorrelation among metrics and after, among metrics and criteria. Also, we obtained that the external influences on the fragments did not occur randomly and that the criteria act on the landscape.

Finally, our results reveal value ranges more suitable for each criterion in the environment under urban sprawl to indicate the occurrence of forest fragments, aiming for functional forest connectivity. 


\section{Declarations}

\section{Acknowledgments}

The authors would also like to acknowledge the Federal University of São Carlos (UFSCAR-Sorocaba) for the opportunity to carry out this study.

\section{Funding}

This work was supported by the São Paulo Research Foundation - FAPESP (process number 2018/21612-8).

\section{Conflicts of interest/Competing interests}

The authors declare that they have no known competing financial interests or personal relationships that could have appeared to influence the work reported in this paper.

\section{Availability of data and material}

Data and materials may be made available.

Code availability

Not applicable

\section{Authors' contributions}

Not applicable

\section{Ethics approval}

Not applicable

\section{Consent to participate}

Not applicable

Consent for publication

Not applicable

\section{References}

1. Abra FD, Huijser MP, Magioli M et al (2021) An estimate of wild mammal roadkill in São Paulo state. Brazil Heliyon 7(1):e06015. https://doi.org/10.1016/j.heliyon.2021.e06015 
2. Acevedo P, Real R, Gortázar C (2011) Favorabilidad ecogeográfica para el corzo: distribución y abundancia. Pirineos 166:9-27. https://doi.org/10.3989/pirineos.2011.166001

3. Adams HR, Barnard HR, Loomis AK (2014) Topography alters tree growth-climate relationships in a semi-arid forested catchment. Ecosphere 5(11):1-16. https://doi.org/10.1890/ES14-00296.1

4. Alamgir M, Campbell MJ, Sloan S et al (2019) High-risk infrastructure projects pose imminent threats to forests in Indonesian Borneo. Sci Rep 9:140. https://doi.org/10.1038/s41598-018-36594-8

5. Almenar JB, Bolowich A, Elliot T et al (2019) Assessing habitat loss, fragmentation and ecological connectivity in Luxembourg to support spatial planning. Landscape Urban Planning 189:335-351. https://doi.org/10.1016/j.landurbplan.2019.05.004

6. Anatoly G, Peng Y, Huemmrich KF (2014) Relationship between fraction of radiation absorbed by photosynthesizing maize and soybean canopies and NDVI from remotely sensed data taken at close range and from MODIS 250m resolution data. Remote Sens Environ, 147:108-120. doi: 10.1016/j.rse.2014.02.014

7. Anselin L (1995) Local Indicators of Spatial Association - LISA. Geographical Analysis 27(2):93115. https://doi.org/10.1111/j.1538-4632.1995.tb00338.x

8. Avalos G, Bermudez E (2016) Effect of a major highway on the spatial and temporal variation in the structure and diversity of the avifauna of a tropical premontane rain forest. Rev biol trop San José 64(4):1383-1399. http://dx.doi.org/10.15517/rbt.v64i4.21517

9. Ayram CAC, Mendonza ME, Etter A et al., 2016. Habitat connectivity in biodiversity conservation: A review of recent studies and applications. Progress in Physical Geography 40(1):7-37. https://doi.org/ 10.1177/0309133315598713

10. Balvanera P, Siddique I, Dee L et al., 2014. Linking Biodiversity and Ecosystem Services: Current Uncertainties and the Necessary Next Steps, BioScience,64(1): 49-57. https://doi.org/10.1093/biosci/bit003

11. Balzotti CS, Asner GP, Adkins ED et al (2020) Spatial drivers of composition and connectivity across endangered tropical dry forests. Journal Applied Ecology 57(8):1593-1604. https://doi.org/10.1111/1365-2664.13632

12. Bar-Massada A, Radeloff VC, Stewart SI (2014) Biotic and Abiotic Effects of Human Settlements in the Wildland-Urban Interface. Bioscience 64(5):429-437. https://doi.org/10.1093/biosci/biu039

13. Bax V, Francesconi W, Quintero M (2016) Spatial modeling of deforestation processes in the Central Peruvian Amazon. Journal of Nature Conservation 29:79-88. https://doi.org/10.1016/j.jnc.2015.12.002

14. Bergsten A, Zetterberg A (2013) To model the landscape as a network: A practitioner's perspective. Landscape Urban Planning 119:35-43.https://doi.org/ 10.1016/j.landurbplan.2013.06.009

15. Blackwell BF, DeVault TL, Fernández-Juricic $E$ et al., 2016. No single solution: application of behavioural principles in mitigating human-wildlife conflict. Animal Behaviour 120(2). https://doi.org/ 10.1016/j.anbehav.2016.07.013 
16. Borcard D, Gillet F, Legendre P (2011) Numerical Ecology with R. Springer Science and Business Media, 306p. Springer, New York. https://doi.org/10.1007/978-1-4419-7976-6

17. Borthagaray Al, Arim M, Marquet PA. Connecting landscape structure and patterns in body size distributions. Oikos. 121(5):697-710. https://doi.org/10.1111/j.1600-0706.2011.19548.x

18. Brasil L Federal n 12651/2012, de 25 de maio de 2012. Dispõe sobre a proteção da vegetação native e dá outras providências. Available in http://www.planalto.gov.br/ccivil_03/_ato20112014/2012/lei/l12651.htm, Accessed on February 12, 2021

19. Carvalho F, Carvalho R, Mira A, Beja $P$ (2015) Assessing landscape functional connectivity in a forest carnivore using path selection functions. Landscape Ecology, 31:1021-1036, 2015. https://doi.org/10.1007/s10980-015-0326-x

20. Cheung AKL, Brierley G, O'Sullivan D (2016) Landscape structure and dynamics on the QinghaiTibetan Plateau. Ecological Modelling 339:7-22. https://doi.org/10.1016/j.ecolmodel.2016.07.015

21. Curiel-Esparza J, Gonzalez-Utrilla N, Canto-Perelo J, Martin-Urilla M (2015) Integrating climate change criteria in reforestation projects using a hybrid decision-support system. Environmental Research Letters 10:e094022. https://doi.org/10.1088/1748-9326/10/9/094022

22. Czarnecka B, Rysiak A, Chabudzinski L (2017) Topographic attributes and ecological indicator values in assessing the ground-floor vegetation patterns. Biodiv. Res. Conserv. 47:9-22, 2017. https://doi.org/10.1515/biorc-2017-0010

23. Da Silva JMF, Santos LJC, Oka-Fiori C (2019) Spatial correlation analysis between topographic parameters for defining the geomorphometric diversity index: application in the environmental protection area of the Serra da Esperança (state of Paraná, Brazil). Environ Earth Sci 78:356. https://doi.org/10.1007/s12665-019-8357-2

24. Deng H, Chen Z, Cao H et al (2015) Perceptions and attitudes of local residents on a nature reserve: a case study in Baimaxueshan National Natural Reserve. International Journal of Sustainable Development World Ecology 22:165-170. https://doi.org/10.1080/13504509.2014.930361

25. Dickie M, McNay SR, Sutherland GD et al (2019) Corridors or risk? Movement along, and use of, linear features varies predictably among large mammal predator and prey species. Journal of Animal Ecology 89(2):623-634. https://doi.org/10.1111/1365-2656.13130

26. Dupras J, Coll F, Marrul J et al., The impacts of urban sprawl on ecological connectivity in the Montreal Metropolitan Region. Historical Landscape Ecology Group. 58:61-73. https://doi.org/10.1016/j.envsci.2016.01.005

27. Economo EP, Keit TH (2010) Network isolation and local diversity in neutral metacommunities. Oikos 119(8):1355-1363. https://doi.org/10.1111/j.1600-0706.2010.18272.x

28. Edelsparre AH, Shahid A, Fitzpatrick MJ (2018) Habitat connectivity is determined by the scale of habitat loss and dispersal strategy. Ecology Evolution 8(11):5508-5514. https://doi.org/10.1002/ece3.4072

29. Fernández IC, Morales NS (2016) A spatial multicriteria decision analysis for selecting priority sites for plant species restoration: a case study from the Chilean biodiversity hotspot. Restoration Ecology 
24(5):599-608. https://doi.org/10.1111/rec.12354

30. Frank S, Fürst C, Koschke L et al., 2013. Assessment of landscape aesthetics-Validation of a landscape metrics-based assessment by visual estimation of the scenic beauty. Ecological Indicators 32:222-231. https://doi.org/ 10.1016/j.ecolind.2013.03.026

31. Gavrilidis AA, Nita MR, Onose D et al., 2019. Methodological framework for urban sprawl control through sustainable planning of urban green infrastructure. Ecol Ind. 96.

https://doi.org/10.1016/j.ecolind.2017.10.054

32. Gibson L, Lee TM, Koh LP et al., 2011. Primary forests are irreplaceable for sustaining tropical biodiversity. Nature 478(7369):378-381. https://doi.org/ 10.1038/nature10425

33. Gonzalez-Garcia A, Palomo I, Gonzalez JA et al (2019) Quantifying spatial supply-demand mismatches in ecosystem services provides insights for land-use planning. Land Use Policy 94:104493. https://doi.org/10.1016/j.landusepol.2020.104493

34. Grădinaru SR, Iojă Cl, Pătru-Stupariu I et al., 2017. Are Spatial Planning Objectives Reflected in the Evolution of Urban Landscape Patterns? A Framework for the Evaluation of Spatial Planning Outcomes" Sustentabilidade. 9(8):1279. https://doi.org/10.3390/su9081279

35. Guo X, Coops NC, Gergel SE, Bater CW, Nielsen SE, Stadt JJ (2018) Integrating airborne lidar and satellite imagery to model habitat connectivity dynamics for spatial conservation prioritization. Landscape Ecol, 33(3):491-511. https:// doi.org/10.1007/s10980-018-0609-0

36. Haidara I, Tahri M, Maanan M et al (2019) Efficiency of Fuzzy Analytic Hierarchy Process to detect soil erosion vulnerability. Geoderma 354:113853. https://doi.org/10.1016/j.geoderma.2019.07.011

37. Hojati M, Mokarram M (2016) Determination of a topographic wetness index using high resolution digital elevation models. European Journal of Geography 7(4):41-52

38. Hollunder RK, Mariotte P, Carrijo TT et al (2021) Topography and vegetation structure mediate drought impacts on the understory of the South American Atlantic Forest. Sci Total Environ 766:144234. https://doi.org/10.1016/j.scitotenv.2020.144234

39. Huang $C$, Huang $X$, Peng $C$ et al., Reconciling the land use conflicts between development and protection. CATENA. 175:388-399. https://doi.org/10.1016/j.catena.2019.01.002

40. Ibánez I, Katz DSW, Peltier D, Wolf S (2014) Assessing the integrated effects of landscape fragmentation on plants and plant communities: The challenge of multiprocess-multiresponse dynamics. 102(4):882-895. https://doi.org/10.1111/1365-2745.12223

41. IBGE - Instituto Brasileiro de Geografia e Estatística (2012) Mapa de Vegetação do Brasil. Available in https://geoftp.ibge.gov.br/informacoes_ambientais/vegetacao/mapas/brasil/vegetacao.pdf. Accessed on march, 2021

42. IBGE - Instituto Brasileiro de Geografia e Estatística (2021) São Paulo/SP. Available in https://cidades.ibge.gov.br/brasil/sp/sao-paulo/panorama. Accessed on march, 2021

43. Isbell FI, Craven D, Connolly J et al (2015) Biodiversity increases the resistance of ecosystem productivity to climate extremes. Nature 7574. https://doi.org/ 10.1038/nature15374 
44. Jesus EN de, Ferreira RA, Aragão AG et al (2015) Estrutura dos fragmentos florestais da bacia hidrográfica do rio Poxim-Se, como subsídio à restauração ecológica. Revista Árvore 39(3):467-474. https://doi.org/10.1590/0100-67622015000300007

45. Jucker T, Bongalov B, Burslem DFRP et al (2018) Topography shapes the structure, composition and function of tropical forest landscapes. Ecology Letters 21(7):989-1000. https://doi.org/10.1111/ele.12964

46. Kane R, John R (2018) Topographical influence on recent deforestation and degradation in the Sikkim Himalaya in India; Implications for conservation of East Himalayan broadleaf forest. Applied Geography 92:85-93. https://doi.org/10.1016/j.apgeog.2018.02.004

47. Keeley ATH, Beier P, Gagnon JW (2016) Estimating landscape resistance from habitat suitability: effects of data source and nonlinearities. Landscape Ecol 31:2151-2162. https://doi.org/10.1007/s10980-016-0387-5. E.

48. Klink J, Aversa M, Empinotti V (2019) On contested water governance and the making of urban financialisation: Exploring the case of metropolitan São Paulo, Brazil. Urban Studies. 57(1): 004209801984439. https://doi.org/ 10.1177/0042098019844390

49. Koen EL, Bowman J, Ellington EH. Mapping landscape connectivity for large spatial extents. Landscape Ecology. 34(2): 2421-2433. https://doi.org/10.1007/s10980-019-00897-6

50. Koprowska K, Laszkiewicz E, Kronenberg J (2020) Is urban sprawl linked to green space availability? Ecological Indicator 108. https:// doi.org/10.1016/j.ecolind.2019.105723

51. Kuang W, Chia W, Lu D, Dou Y (2014) A comparative analysis of megacity expansions in China and the U.S.: Patterns, rates and driving forces. Landscape and Urban Planning. 133:121-135. https:// doi.org/10.1016/j.landurbplan.2014.08.015

52. La Fuente B, Mateo-Sánchez MC, Rodriguez G et al (2018) Natura 2000 sites, public forests and riparian corridors: The connectivity backbone of forest green infrastructure. Land Use Policy 75:429441. https://doi.org/10.1016/j.landusepol.2018.04.002

53. Lakicev M, Srdjevic Z, Srdjevic B, Zlatic M (2014) Decision making in urban forestry by using approval voting and multicriteria approval method (case study: Zvezdarska forest, Belgrade, Serbia). Urban Forestry and Urban Greening. 13(1):114-120. https://doi.org/10.1016/j.ufug.2013.11.001

54. Lausch A, Herzog F (2002) Applicability of landscape metrics for the monitoring of landscape change: Issues of scale, resolution and interpretability. Ecological Indicators 1(2):3-15. https://doi.org/10.1016/S1470-160X(02)00053-5

55. Lechner AM, Reinke K, Wang Y, Bastin L (2013) Interactions between landcover pattern and geospatial processing methods: Effects on landscape metrics and classification accuracy. Ecological Complexity 15:71-82. https://doi.org/10.1016/j.ecocom.2013.03.003

56. Lelli C, Bruum HH, Chiarucci A et al (2018) Biodiversity response to forest structure and management: Comparing species richness, conservation relevant species and functional diversity as metrics in forest conservation. Forest Ecology Management 432:707-717. https://doi.org/10.1016/j.foreco.2018.09.057 
57. Lembi RC, Cronemberger C, Picharillo C et al (2020) Urban expansion in the Atlantic Forest: applying the Nature Futures Framework to develop a conceptual model and future scenarios. Biota Neotrop e20190904. https://doi.org/10.1590/1676-0611-bn-2019-0904

58. Li N, Chu H, Qi Y et al (2019) Alpha and beta diversity of birds along elevational vegetation zones on the southern slope of Altai Mountains: Implication for conservation. Global Ecology Conservation 19:e00643. https://doi.org/10.1016/j.gecco.2019.e00643

59. Li Y, Viña A, Yang W et al (2013) Effects of conservation policies on forest cover change in giant panda habitat regions, China. Land Use Policy 33:42-53. https://doi.org/10.1016/j.landusepol.2012.12.003

60. Lin BB, Fuller RA (2013) FORUM: Sharing or sparing? How should we grow the world's cities? Journal of Applied Ecology 50(5):1161-1168. https://doi.org/10.1111/1365-2664.12118

61. Loritz R, Jackisch C, Kleidon A et al., 2017. A topographic index explaining hydrological similarity by accounting for the joint controls of runoff formation. Hidrology Earth System Sciences 23(9):38073821. https://doi.org/ 10.5194/hess-23-3807-2019

62. Loro M, Ortega E, Arce RM et al., 2016. Assessing landscape resistance to roe deer dispersal using fuzzy set theory and multicriteria analysis: a case study in Central Spain. Landscape Ecol Eng 12:41-60. https://doi.org/ 10.1007/s11355-015-0275-1

63. Madadi H, Moradi H, Soffianian A et al (2017) Degradation of natural habitats by roads: Comparing land-take and noise effect zone. Environ Impact Asses 65:147-155. https://doi.org/10.1016/j.eiar.2017.05.003

64. Magioli M, Moreira MZ, Fonseca RC, B., et al (2019) Human-modified landscapes alter mammal resource and habitat use and trophic structure. PNAS 37:18466-18472. https://doi.org/10.1073/pnas.1904384116

65. Matos C, Petrovan SO, Wheeler PM et al (2019) Landscape connectivity and spatial prioritization in an urbanising world: A network analysis approach for a threatened amphibian. Biological Conservation 237:237-247. https://doi.org/10.1016/j.biocon.2019.06.035

66. McDonald RI, Marcotulio PJ, Guneralp B (2013) Urbanization and global trends in biodiversity and ecosystem services. In: Elmqvist T, Fragkias M, Goodness J, Güneralp B, Marcotullio PJ, McDonald RI, Parnell S, Schewenius M, Sendstad M, Seto KC, Wilkinson C (eds) Urbanization, biodiversity and ecosystem services: Challenges and opportunities. Springer, Netherlands, pp 32-52

67. McGarigal K (2013) Landscape Pattern Metrics. Encyclopedia of Environmetrics.https://doi.org/10.1002/9780470057339.val006.pub2

68. McPherson SC, Brown M, Downs CT (2016) Diet of the crowned eagle (Stephanoaetus coronatus) in an urban landscape: potential for human-wildlife conflict? Urban Ecosyst 19:383-396. https://doi.org/10.1007/s11252-015-0500-6

69. McRae BH, Hall SA, Beier P et al (2012) Where to Restore Ecological Connectivity? Detecting Barriers and Quantifying Restoration Benefits. Plos One 7(12):e52604. https://doi.org/10.1371/journal.pone.0052604 
70. Mello K, Costa DR, Valente R, Vettorazzi A, C. D (2018) Multicriteria Evaluation for Protected Area Definition Aiming at Water Quality Improvement. Floresta e Ambiente 25(3):e20160134. https://doi.org/10.1590/2179-8087.013416

71. Mello K, Taniwaki RH, Paula FR et al (2020) Multiscale land use impacts on water quality: Assessment, planning, and future perspectives in Brazil. Journal of Environmental management 270:110879. https://doi.org/10.1016/j.jenvman.2020.110879

72. Mello K, Toppa RH, Cardoso-Leite E (2016) Priority area for forest conservation in an urban landscape at the transition between Atlantic forest and Cerrado. Cerne 22(3):277-288. https://doi.org/ 10.1590/01047760201622032172

73. Merrick MJ, Koprowski JL (2017) Circuit theory to estimate natal dispersal routes and functional landscape connectivity for an endangered small mammal. Landscape Ecol 32:1163-1179. https://doi.org/ 10.1007 / s10980-017-0521-z

74. Mimet A, Clauzel C, Foltête JC (2016) Locating wildlife crossing for multispecies connectivity across linear infrastructures. Landscape Ecology 31(9). https://doi.org/10.1007/s10980-016-0373-y

75. Ministério do Meio Ambiente (MMA) (2021) Áreas prioritárias para conservação da biodiversidade brasileira. http://areasprioritarias.mma.gov.br/1-atualizacao-das-areas-prioritarias / (Accessed on March 8, 2021)

76. Mitchell SL, Edwards DP, Bernard H et al., Riparian reserves help protect forest bird communities in oil palm dominated landscapes. Journal of Applied Ecology. 55(6):2744-2755. https://doi.org/10.1111/1365-2664.13233

77. Molin PG, Robin C, Ferraz S, Brancalion FB, P. H. S (2018) A landscape approach for cost-effective large-scale forest restoration. Journal of Applied Ecology 55(6):2767-2778. https://doi.org/10.1111/1365-2664.13263

78. Nagai S, Nasahara KN, Muraoka H et al (2010) Field experiments to test the use of the normalizeddifference vegetation index for phenology detection. Agricultural Forest Meteorology 150(2):152160. https://doi.org/10.1016/j.agrformet.2009.09.010

79. Newbold T, Hudson L, Hill S et al (2015) Global effects of land use on local terrestrial biodiversity. Nature 520:45-50. https://doi.org/10.1038/nature14324

80. O'Neil GL, Goodall JL, Watson LT (2018) Evaluating the potential for site-specific modification of LiDAR DEM derivatives to improve environmental planning-scale wetland identification using Random Forest classification. Journal of Hydrology 559:192-208. https://doi.org/10.1016/j.jhydrol.2018.02.009

81. Ojima R (2007) Dimensões da urbanização dispersa e proposta metodológica para estudos comparativos: uma abordagem socioespacial em aglomerações urbanas brasileiras. R Brasileira de Estudos de População 24(2):277-300. https:// doi.org/10.1590/S0102-30982007000200007

82. Otero I, Marull J, Tello E, G. L. et al (2015) Land abandonment, landscape, and biodiversity: questioning the restorative character of the forest transition in the Mediterranean. Ecology Society 20(2):7. http://doi.org/10.5751/ES-07378-200207 
83. Ou Z, He SPQ, Peng Y et al (2020) Effects of vegetation restoration and environmental factors on understory vascular plants in a typical karst ecosystem in southern China. Sci Rep 10:12011. https://doi.org/10.1038/s41598-020-68785-7

84. Palmero-Iniesta M, Espelta JM, Gordillo J et al., 2020. Changes in forest landscape patterns resulting from recent afforestation in Europe (1990-2012): defragmentation of pre-existing forest versus new patch proliferation. Animals of Forest Science. 77(43). https://doi.org/10.1007/s13595-020-00946-0

85. Pays O, Fortin D, Gassani J, Duchesne J, 201.Group dynamics and landscape features constrain the exploration of herds in fusionfission societies: the case of European Roe 7(3):1-8. https://doi.org/10.1371/journal.pone.0034678

86. Pelletier D, Lapointe ME, Wulder MA et al (2017) Forest Connectivity Regions of Canada Using Circuit Theory and Image Analysis. Plos One. https://doi.org/10.1371/journal.pone.0169428

87. Pereira HM, Ferrier S, Walters M et al., 2013. Essential biodiversity variables. Science 339 (80-.), 277278. http://dx.doi.org/10.1126/ science.1229931

88. Pirnat J, Hladnik D (2018) The Concept of Landscape Structure, Forest Continuum and Connectivity as a Support in Urban Forest Management and Landscape Planning. Forests 9(10):584. https:// doi.org/10.3390/f9100584

89. Ramesh T, Kalle R, Downs CT (2015) Sex-specific indicators of landscapes use by servals: Consequence of living in fragmented landscapes. Ecol Ind 52:8-15. https://doi.org/10.1016/j.ecolind.2014.11.021

90. Ramey TL, Richardson JS (2017) Terrestrial Invertebrates in the Riparian Zone: Mechanisms Underlying Their Unique Diversity. Bioscience 67(9):808-819. https://doi.org/10.1093/biosci/bix078

91. Ribeiro MP, Mello K, Valente RA (2020) Avaliação da estrutura da paisagem visando à conservação da biodiversidade em paisagem urbanizada. Ciência Florestal 30(3):819-834. .https://doi.org/10.5902/1980509837683. Epub October 26, 2020

92. Rincón V, Velázquez J, Gutiérrez J, Sánchez B et al (2018) Evaluating European Conservation Areas and Proposal of New Zones of Conservation under the Habitats Directive. Application to Spanish Territories Sustainability 11(2):398. https://doi.org/10.3390/su11020398

93. Romero AC, Issii TM, Pereira-Silva EFL et al. 2018.effects of urban sprawl on forest conservation in a metropolitan water source area. Revista Árvore, 42 (1):e420114. https://doi.org/10.1590/180690882018000100014

94. Ruffel J, Clout MN, Didham RK (2017) The matrix matters, but how should we manage it? Estimating the amount of high-quality matrix required to maintain biodiversity in fragmented landscapes. Ecography 40(1):171-178. Htttps://doi.org/10.1111/ecog.02097

95. Russo IRM, Sole CL, Barbato M et al (2016) Landscape determinants of fine-scale genetic structure of a small rodent in a heterogeneous landscape (Hluhluwe-iMfolozi Park, South Africa). Sci Rep 6:29168. https://doi.org/10.1038/srep29168

96. Santos AR, Silva RCF, Assis LC et al (2019) Defining environmental conservation levels considering anthropic activity in the Uberaba River Basin protected area. Revista Ambiente Água 14(1):e2279. 
.https://doi.org/10.4136/ambi-agua.2279

97. Saura S, Bastin L, Battistella L et al (2017) Protected area connectivity: Shortfalls in global targets and country-level priorities. Biological Conservation 219:53-67. https://doi.org/10.1016/j.biocon.2017.12.020

98. Schindler S, VonWehrden H, Poirazidis K et al (2015) Performance of methods to select landscape metrics for modelling species richness. Ecol Model 295(c):107-112. https://doi.org/10.1016/j.ecolmodel.2014.05.012

99. Schindler S, von Wehrden H, Poirazidis K et al (2013) Multiscale performance of landscape metrics as indicators of species richness of plants, insects and vertebrates. Ecological Indicators 31:41-48. https://doi.org/10.1016/j.ecolind.2012.04.012

100. Scriven SA, Carlson KM, Hodgson JA et al., 2019. Testing the benefits of conservation set-asides for improved habitat connectivity in tropical agricultural landscape. 55(10):2274-2285. https://doi.org/10.1111/1365-2664.13472

101. Semper-Pascual A, Macchi L, Sabatini F, M., et al (2018) Mapping extinction debt highlights conservation opportunities for birds and mammals in the South Amercian Chaco. J Appl Ecol 55(3):1218-1229. https://doi.org/10.1111/1365-2664.13074

102. Senzaki M, Yamaura Y (2016) Surrogate species versus landscape metric: does presence of a raptor species explains diversity of multiple taxa more than patch area? Wetlands Ecology Management 24(4):427-441. https://doi.org/10.1007/s11273-015-9469-4

103. Shiferaw H, Bewket W, Alamirew T et al (2019) Implications of land use/land cover dynamics and Prosopis invasion on ecosystem service values in Afar Region, Ethiopia. Science of the Total Environment 675:354-366. https://doi.org/10.1016/j.scitotenv.2019.04.220

104. Silva VAM, Mello K de, Vettorazzi CA, Costa DR, da, Valente RA (2017) Priority Areas for Forest Conservation, Aiming at the Maintenance of Water resources. Through the Multicriteria Evaluation Revista Árvore 41(1):e410119. https://doi.org/10.1590/1806-90882017000100019

105. Tabor G, Ayran CAC, Garcia LC et al (2019) Ecological connectivity: a bridge to preserving biodiversity. In: Frontiers 2018/19 Emerging Issues of Environmental Concern (Nairobi: United Nations. Environment Programme, pp 24-37

106. Tarabon S, Bergés L, Dutoit T et al., 2019. Maximizing habitat connectivity in the mitigation hierarchy. A case study on three terrestrial mammals in an urban environment. J Environ Manage 1:243-340.https://doi.org/ 10.1016/j.jenvman.2019.04.121

107. Thompson PL, Rayfield B, Gonzalez A (2017) Loss of habitat and connectivity erodes species diversity, ecosystem functioning, and stability in metacommunity networks. Ecography 40(1):98108. https://doi.org/10.1111/ecog.02558

108. Torrella SA, Piquer-Rodriguez M, Levers C et al (2018) Multiscale spatial planning to maintain forest connectivity in the Argentine Chaco in the face of deforestation. Ecology Society 23(4):37. https://doi.org/10.5751/ES-10546-230437 
109. Torres A, Jaeger JAG, Alonso JC (2016) Multi-scale mismatches between urban sprawl and landscape fragmentation create windows of opportunity for conservation development. Landscape Ecol 31:2291-2305. https://doi.org/10.1007/s10980-016-0400-z

110. Tucker MA, Gaese KB, Fagan WF et al (2018) Moving in the anthropocene: global reductions in terrestrial mammalian movements. Science 359(6374):466-469. https://doi.org/10.1126/science.aam9712

111. Uezu A, Metzger JP, Vielliard JME (2005) Effects of structural and functional connectivity and patch size on the abundance of seven Atlantic Forest bird species. Biological Conservation 123(4):507519. https://doi.org/ 10.1016/j.biocon.2005.01.001

112. Unda M, Etter A (2019) Conservation Opportunities of the Land Restitution Program Areas in the Colombian Post-Conflict Period. Sustainability. 11(7), 2048. https://doi.org/10.3390/su11072048

113. Union Nations Educations, Scientific and Cultural Organization (UNESCO) (2019) Biosphere Reserves. https://en.unesco.org/biosphere / (Accessed on November 20, 2019)

114. Valente RA, Petean FCS, Vettorazzi CA (2017) Multicriterial decision analysis for prioritizing areas for forest restoration. CERNE 23(1):53-60. https://doi.org/10.1590/01047760201723012258

115. Valente RA, Petean FCS, Vettorazzi CA (2017) Multicriteria decision analysis for prioritizing areas for forest restoration. Cerne 23(1):53-60. https://doi.org/10.1590/01047760201723012258

116. Valladares GS et al (2012) Modelo multicritério aditivo na geração de mapas de suscetibilidade à erosão em área rural. Pesquisa Agropecuária Brasileira 47(9):1376-1383. http://doi.org/10.1590/S0100-204X2012000900023

117. Van Geert A, Van Rossum F, Triest L (2009) Do linear landscape elements in farmland act as biological corridors for pollen dispersal? Journal of Ecology 98(1):178-187. https://doi.org/10.1111/j.1365-2745.2009.01600.x

118. Vettorazzi CA, Valente R, A (2016) Priority areas for forest restoration aiming at the conservation of water resources. Ecological Engineering 94:255-267. https://doi.org/10.1016/j.ecoleng.2016.05.069

119. Victor RABM, Neto JBC, Ab'Saber AN et al., 2004. Application of the Biosphere Reserve Concept to Urban Areas: The Case of São Paulo City Green Belt Biosphere Reserve, Brazil-São Paulo Forest Institute: A Case Study for UNESCO. Urban Ecosphere and Society Partnership of Cities. 1023(1):237-281. https://doi.org/10.1196/annals.1319.012

120. Wagner FH, Sanchez A, Aidar MPM et al (2020) Mapping Atlantic rainforest degradation and regeneration history with indicator species using convolutional network. PLoS ONE 15(2):e0229448. https://doi.org/10.1371/journal.pone.0229448

121. Wang S, Loreau M (2016) Biodiversity and ecosystem stability across scales in metacommunities. Ecol Lett 19(5):510-518. https://doi.org/10.1111/ele.12582

122. Watson JE, Shanahan DF, Marco MD et al (2016) Catastrophic declines in wilderness areas undermine global environment targets Current Biology. 26(21):2929-2934. https://doi.org/10.1016/j.cub.2016.08.049 
123. Wood E, Pidgeon AM, Radeloff VC, Kueler N (2013) Image texture predicts avian density and species richness PLoS ONE. 8(5):e63211. https://doi.org/10.1371/journal.pone.0063211

124. Yabsley NA, Olds AD, Connolly RM et al (2016) Resource type influences the effects of reserves and connectivity on ecological functions. Journal of Animal Ecology 85(2):437-444. https://doi.org/10.1111/1365-2656.12460

125. Yuan Y, Chen D, Wu S et al (2019) Urban sprawl decreases the value of ecosystem services and intensifies the supply scarcity of ecosystem services in China. Science of the Total Environment 697:134170. https://doi.org/10.1016/j.scitotenv.2019.134170

126. Yuan Y, Chen D, Wu S et al., 2019. Urban sprawl decreases the value of ecosystem services and intensifies the supply scarcity of ecosystem services in China. Science of the Total Environment 20 (697):134170. https://doi.org/ 10.1016/j.scitotenv.2019.134170

127. Zeller KA, McGarigal K, Whiteley A (2012) Estimating landscape resistance to movement: a review. Landscape Ecol 27:777-797. https://doi.org/10.1007/s10980-012-9737-0

128. Zhang L, Liu S, Sun P, Wang T (2016) Using DEM to predict Abies faxoniana and Quercus aquifolioides distributions in the upstream catchment basin of the Min River in southwest China. Ecology Indicator, 69:91-99. https://doi.org/ 10.1016/j.ecolind.2016.04.008

129. Zhang Z, Zinda JA, Yang Z et al (2018) Effects of topographic attributes on landscape pattern metrics based on redundancy ordination gradient analysis. Landscape Ecological Engineering 14:67-77. https://doi.org/10.1007/s11355-016-0322-6

130. Zimbres B, Peres CA, Penido G et al., 2018. Thresholds of riparian forest use by terrestrial mammals in a fragmented Amazonian deforestation frontier. Biodiversity Conservation 27(11):2815-2836. https://doi.org/ 10.1007/s10531-018-1571-5

131. Ziter C, Bennett EM, Gonzalez A (2013) Functional diversity and management mediate carbon storage in small forest fragments. Ecosphere 4(7). https://doi.org/10.1890/ES13-00135.1

\section{Figures}



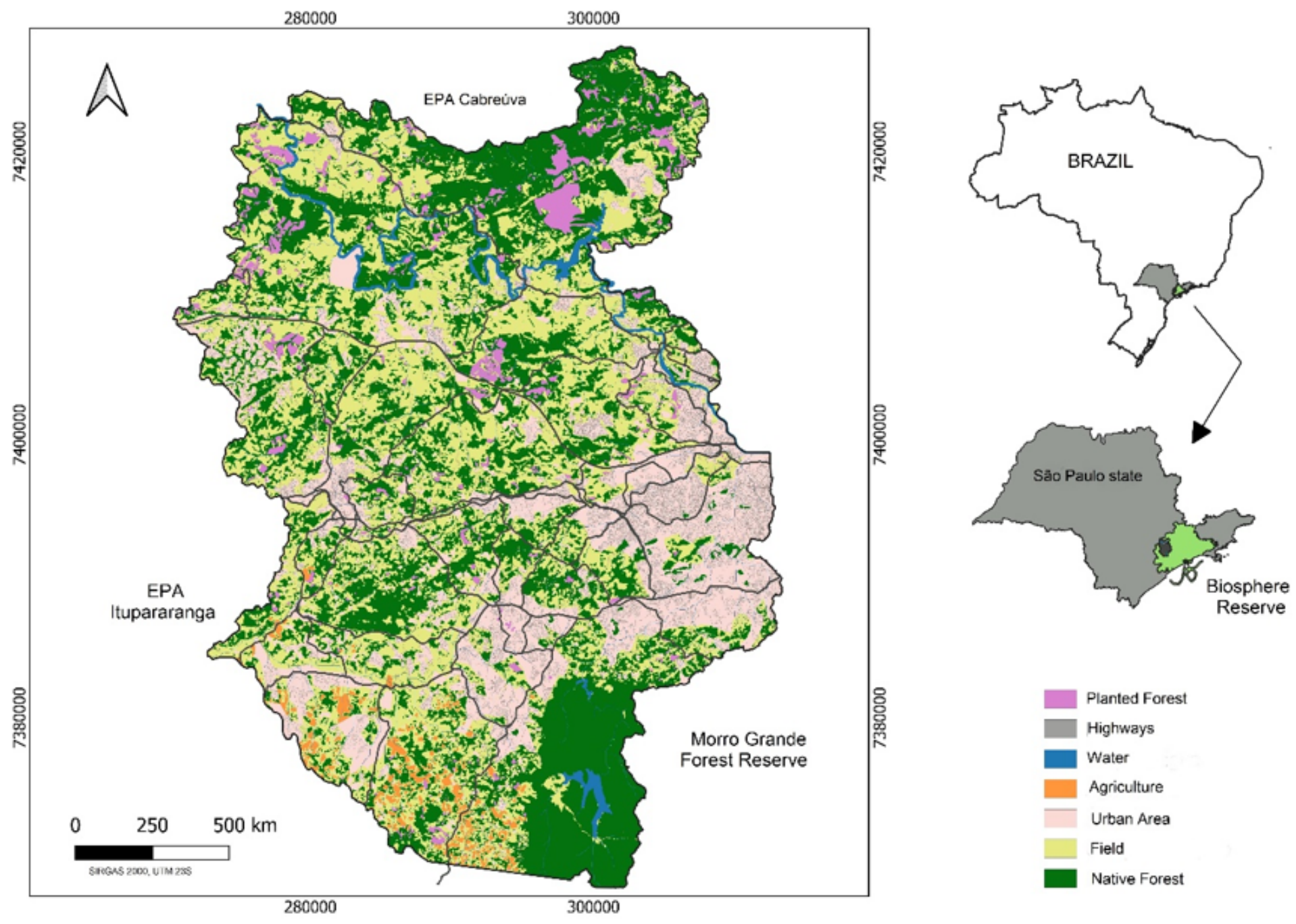

\section{Figure 1}

Location and land-use/land-cover of the study area in the Green Belt Biosphere Reserve of São Paulo City, (GBBR-SP), Brazil. Note: The designations employed and the presentation of the material on this map do not imply the expression of any opinion whatsoever on the part of Research Square concerning the legal status of any country, territory, city or area or of its authorities, or concerning the delimitation of its frontiers or boundaries. This map has been provided by the authors. 


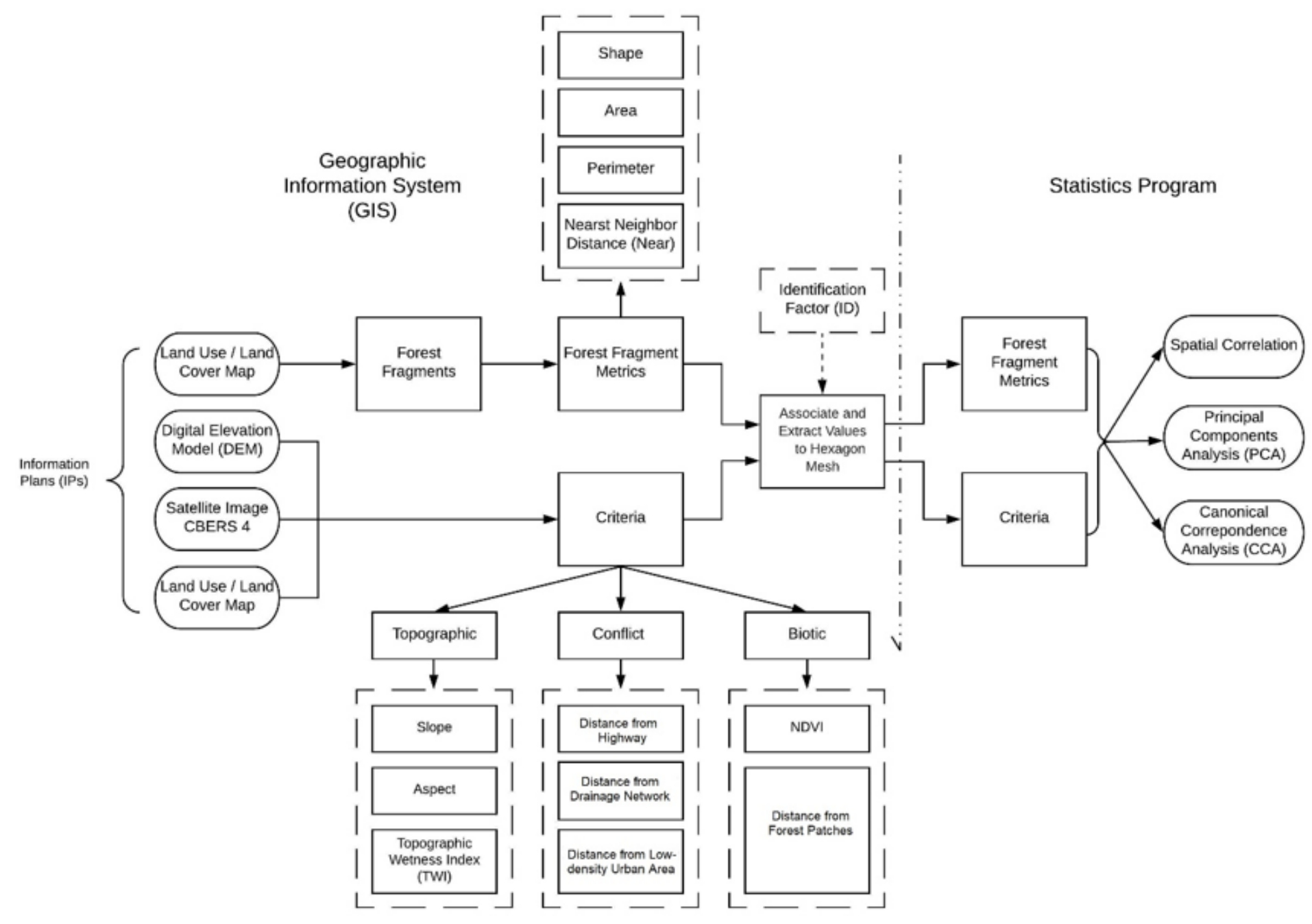

Figure 2

Conceptual Model for the Study Landscape Located in the São Paulo City's Green Belt Biosphere Reserve, São Paulo State, Brazil. 


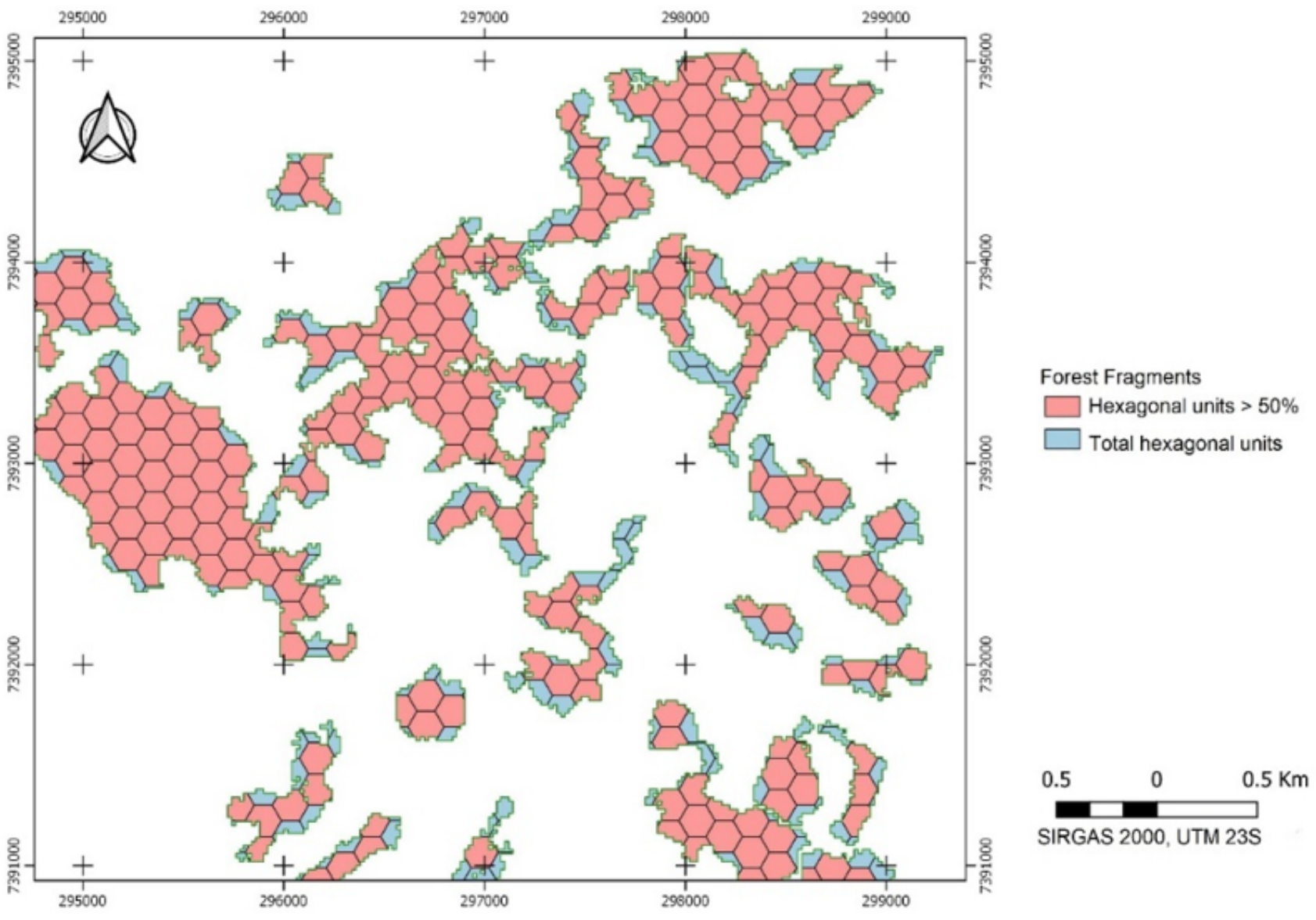

Figure 3

Forest patches and hexagonal network, that was used to criteria evaluation of the study area in the GBBRSP, Brazil. 


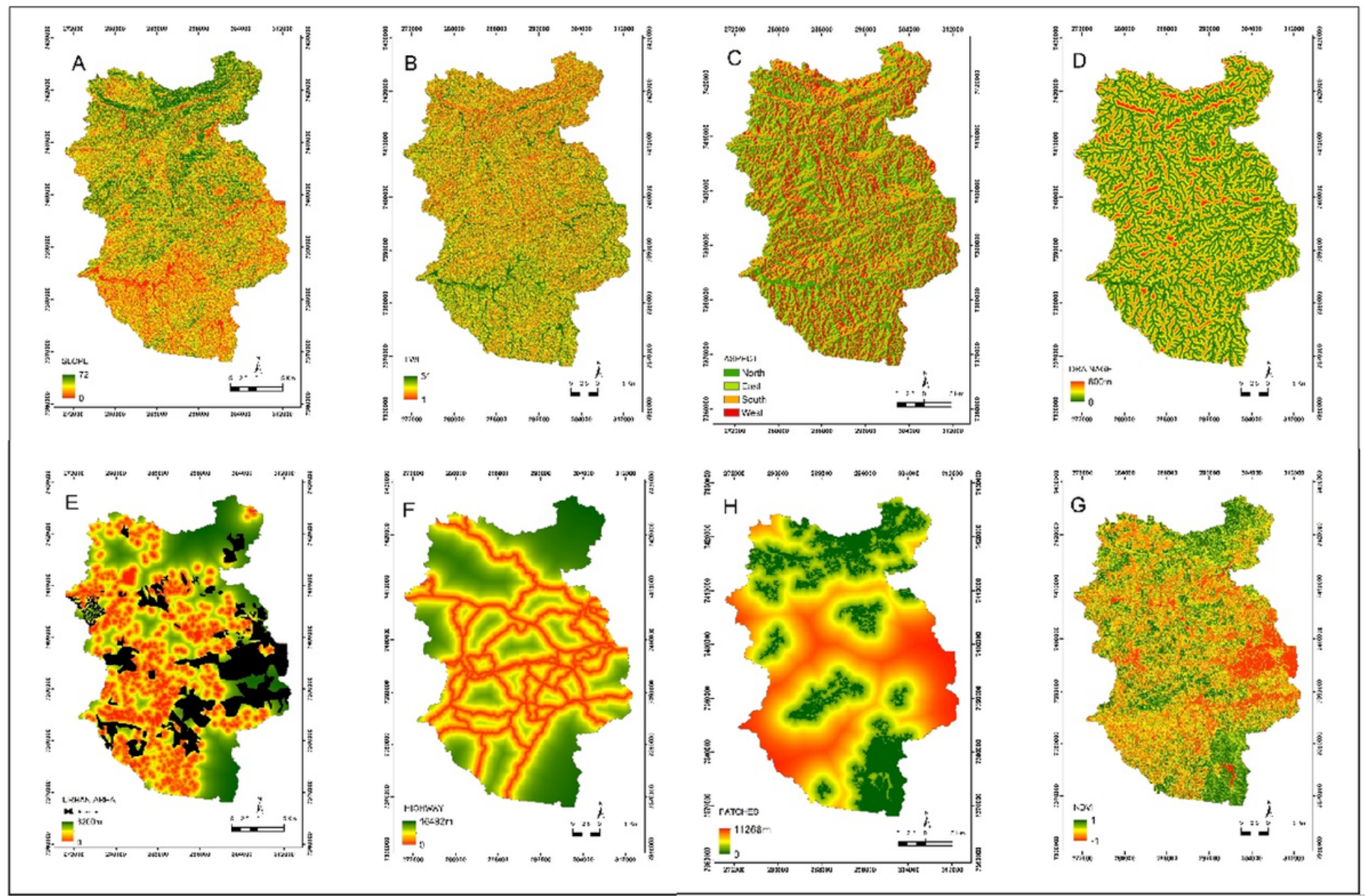

Figure 4

Environmental criteria set produced for the study area in the GBBR-SP, Brazil: (A) slope, (B) TWI, (C) Aspect, (D) Distance from drainage network, $(E)$ Distance from the low-density urban area, $(F)$ Distance from highway, (G) Distance from forest patches, and (H) NDVI. 


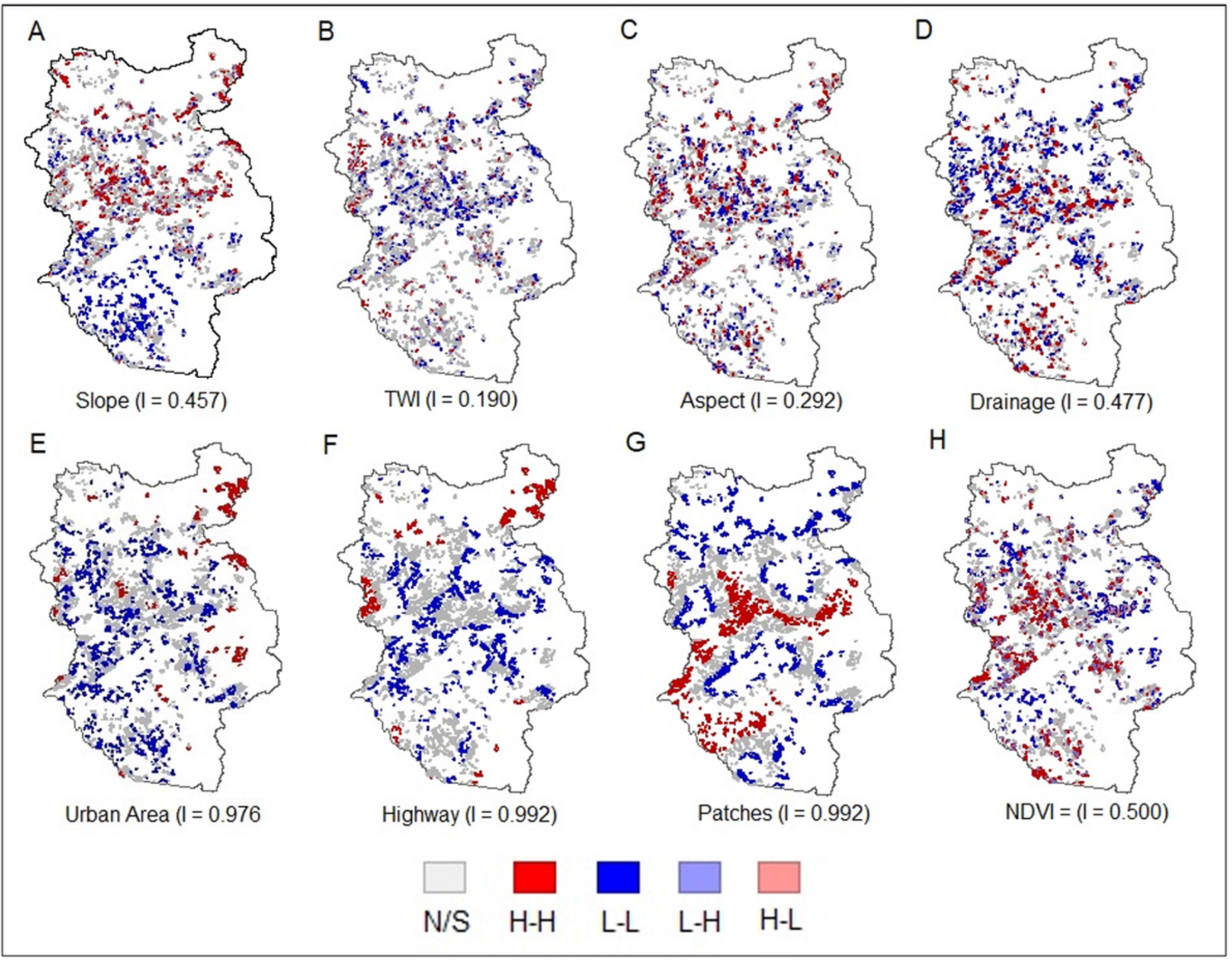

\section{Figure 5}

Spatialization of the Moran Global (Moran I) and the Moran Local (LISA) indexes for the criteria: A) slope, (B) TWI, (C) Aspect, (D) Distance from drainage network, (E) Distance from the low-density urban area, (F) Distance from highway, (G) Distance from forest patches, and (H) NDVI. Where: Urban Area = LowDensity Urban Area; Highway = Distance from Highways; Patches = Distance from Patches; N/S = Not Significant; H-H = High-High; L-L = Low-Low; L-H = Low-High; H-L = High-Low. 


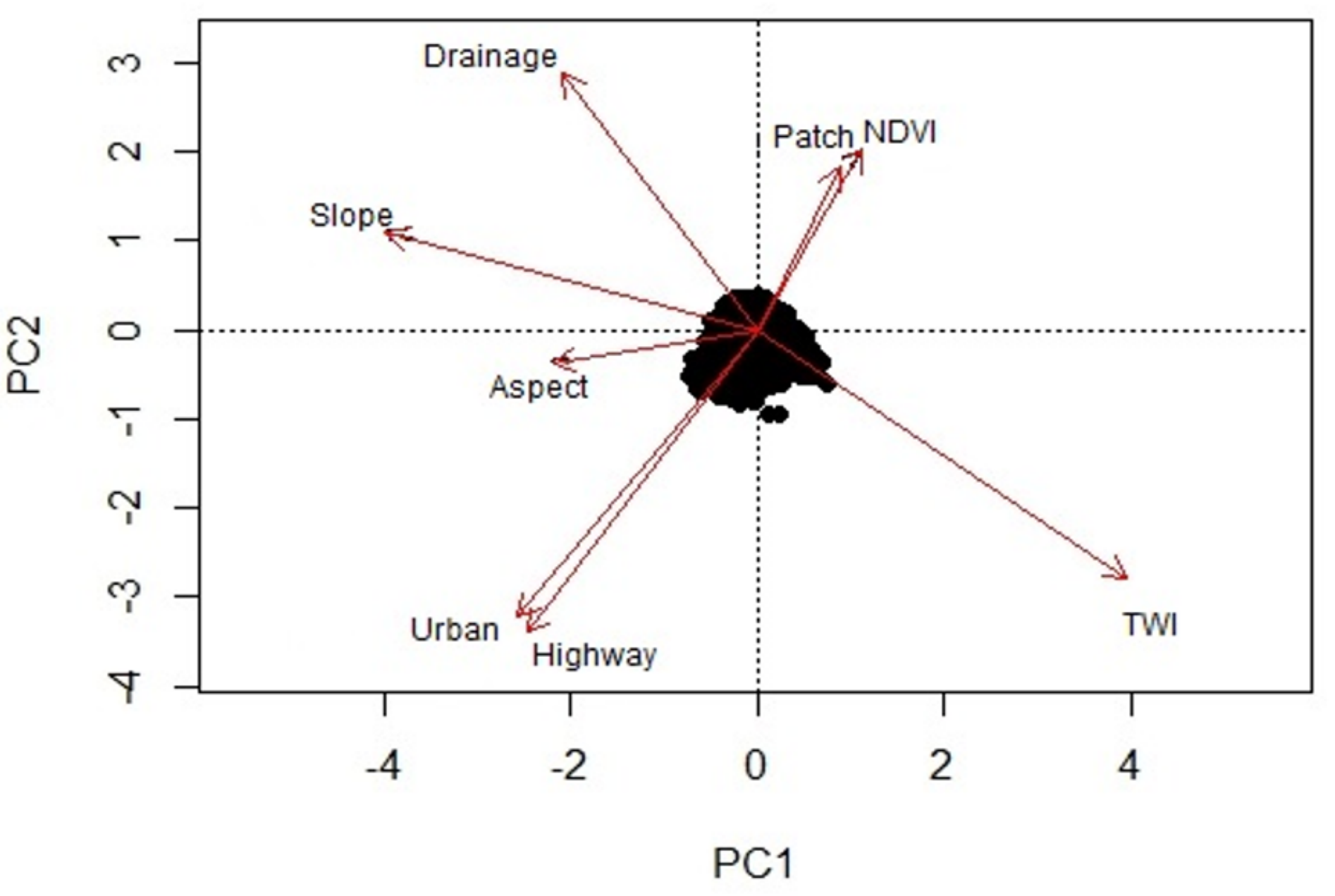

Figure 6

PCA analysis for the criteria variability evaluation, for the study area in the GBBR-SP, Brazil

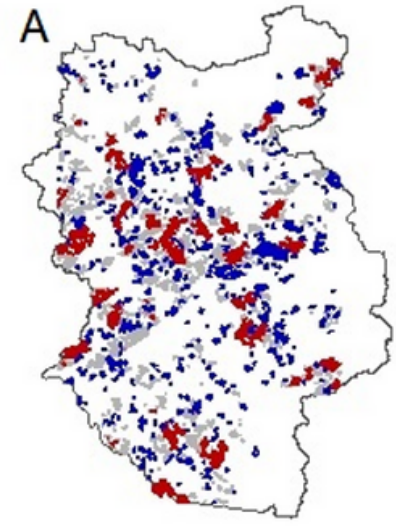

Shape $(I=0.963)$

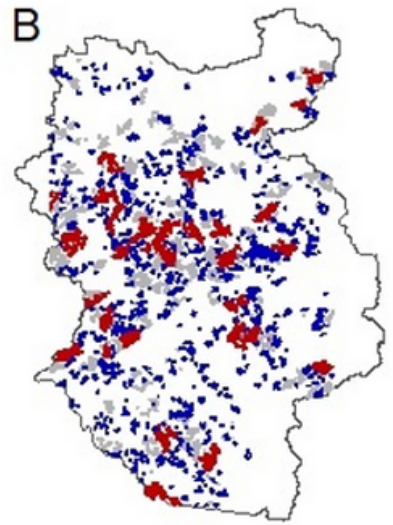

Perimeter $(1=0.968)$

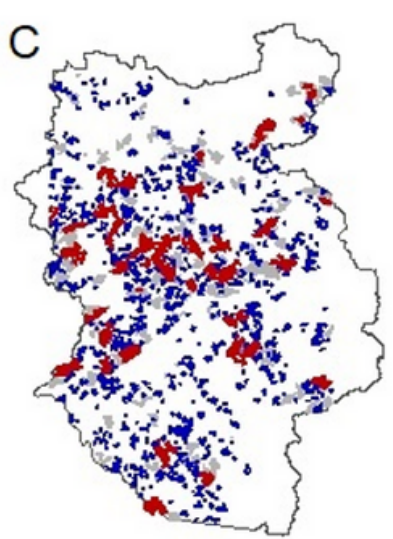

Area $(1=0.971)$

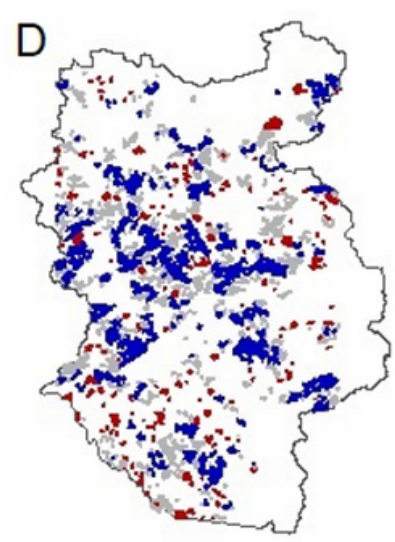

Near $(I=1.000)$

\section{Figure 7}

Moran Index (I) and Local Spatial Autocorrelation (LISA) for Criteria in the for the study area in the GBBRSP, Brazil: (A) Shape; (B) Perimeter; (C) Area; D (Near). 


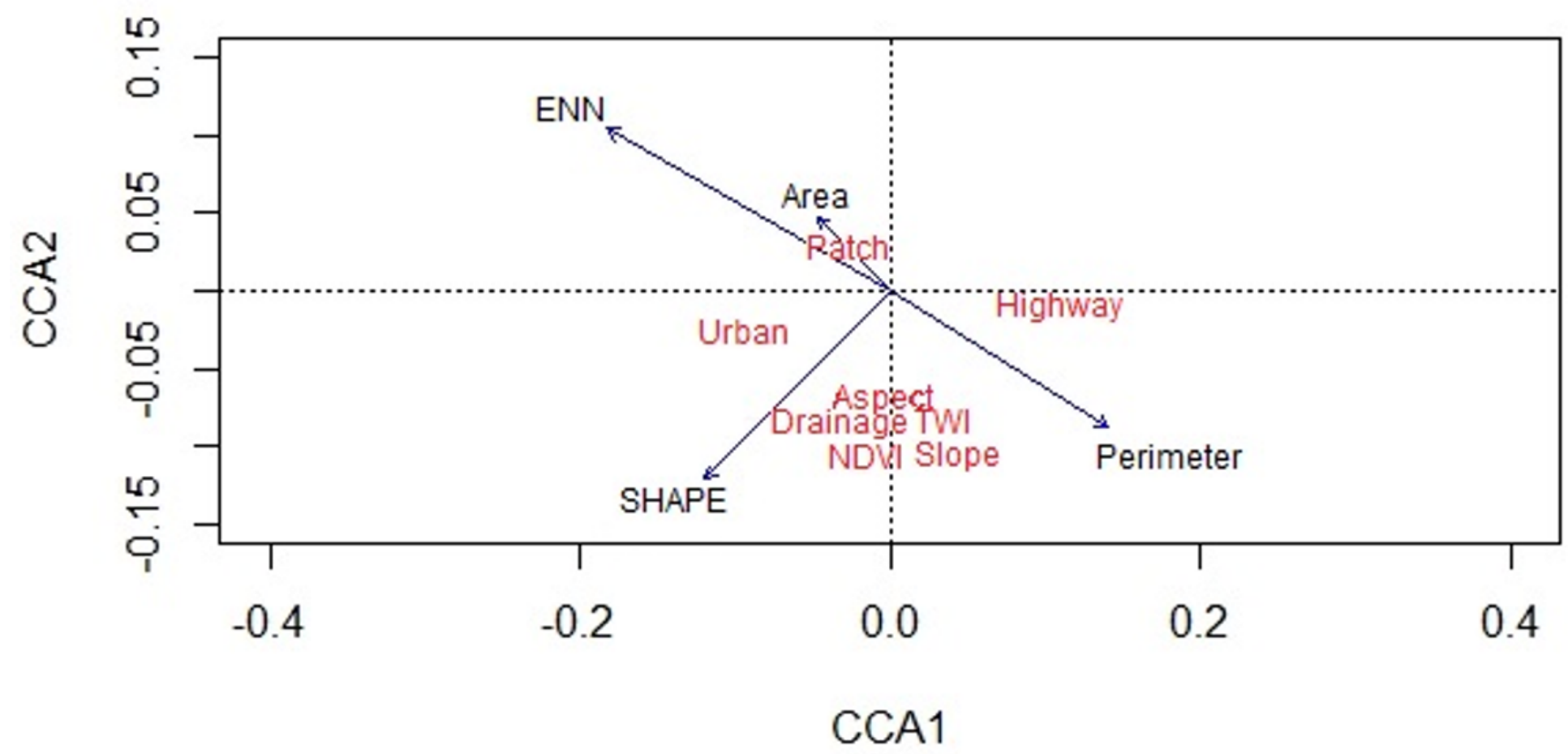

Figure 8

Canonical Correspondence Analysis (CCA) applied to the criteria according to fragment metrics of the study in the GBBR-SP, Brazil. 